\title{
The Morphosyntax of Embedded Clauses in Western Neo-Aramaic: Arabic Influence or Retention from Older Aramaic?
}

\author{
IvriJ. Bunis | ORCID: 0000-0003-4239-4186 \\ Research Associate, Department of Hebrew, Faculty of Asian and Middle \\ Eastern Studies, University of Cambridge, Cambridge, UK \\ ib423@cam.ac.uk
}

\begin{abstract}
The article asks whether the morphosyntax of embedded direct object clauses and purpose clauses in Western Neo-Aramaic reflects retention from older stages of Aramaic, or innovation under the influence of contact Arabic. To this end, direct object clauses and purpose clauses are analysed in Western Neo-Aramaic, in older stages of Aramaic, namely, Old, Official, Biblical and Qumran Aramaic, as well as Syriac, the three Western Late Aramaic dialects (CPA, JPA, SA), and in contemporaneous Syrian Arabic. The analysis considers the embedded verb form, the formal means of linking the embedded clause to the matrix clause, and the co-referentiality of the matrix and embedded subjects, and relates these features to tense-aspect-mood. The article compares the constructions in the various sources of Aramaic and Syrian Arabic and finds features that Western Neo-Aramaic has retained from Late Aramaic, which differ from Syrian Arabic, despite the well documented influence of the latter.
\end{abstract}

\section{Keywords}

historical morphosyntax - Western Aramaic - Western Neo-Aramaic - embedded clauses - language contact - Syrian Arabic 
The current article seeks to uncover the historical background to the morphosyntax of direct object complement clauses and adverbial clauses expressing purpose in Western Neo-Aramaic (WNA). To achieve this objective, constructions that serve in these functions are examined in WNA, in older varieties of Aramaic beginning with Old Aramaic (OA), and in contemporaneous Syrian Arabic (SARB) as a possible donor language.

The examined constructions were selected on the basis of the following morphosyntactic feature: they all may be expressed as infinitive clauses with only the element $l$ - linking them to the predicate. Already in OA, this morphosyntactic feature is shared by direct object clauses and purpose clauses, apparently an inheritance from a 'proto-Aramaic' stage. ${ }^{2}$ The shared morphosyntax suggests that they were comparable in grammatical status. The expression of direct object and purpose clauses by the same morphosyntax is found in other Semitic languages, such as Classical Arabic and Hebrew. ${ }^{3}$

One feature of direct object complement clauses and purpose clauses in WNA is that they are commonly asyndetic, i.e., lack any subordinator. Conversely, when they are explicitly linked by a subordinator, it does not consist of a reflex of older Aramaic $d$-, as is found in older Aramaic dialects. Rather, such subordinators are either forms borrowed from Arabic, or innovations, perhaps under the influence of Arabic. The widespread asyndetic linking of these direct object complement clauses and purpose clauses constitutes a different development from what Na'ama Pat-El has found to have characterised adverbial clauses in Late Aramaic (LA).

1 List of abbreviations and glosses: ADJ Adjective; BA Biblical Aramaic; Cs Construct state; DEF Definite; CPA Christian Palestinian Aramaic; CTP Complement taking predicate; Do Direct object; IND Indicative; IN DF Indefinite; IN F Infinitive; IO Indirect object; I R R Irrealis; JPA Jewish Palestinian Aramaic; LA Late Aramaic; OA Old Aramaic; OFEA Official Egyptian Aramaic; PART Participle; PASS Passive; PN Proper noun; PERF Perfect; PRET Preterite; PROG Progressive; QA Qumran Aramaic; REL Relativiser; SA Samaritan Aramaic; SARB Syrian Arabic; SU BRD Subordinator; svC Serial verb construction; TAM Tense-aspect-mood; wLA Western Late Aramaic; wNA Western Neo-Aramaic.

2 N. Pat-El, Studies in the Historical Syntax of Aramaic (Perspectives on Linguistics and Ancient Languages, 1, Piscataway, NJ: Gorgias, 2012) pp. 34-35.

3 See for instance M.M. Bravmann, Studies in Semitic Philology (ssLL, VI, Leiden: Brill, 1977) pp. 227-229; R. Hasselbach, Case in Semitic: Roles, Relations, and Reconstruction (Oxford: Oxford University Press, 2013) pp. 266-298, especially 292 and 294-298. In addition, see W. Wright, A Grammar of the Arabic Language, vol. 2 (Cambridge: Cambridge University Press, 3rd edn, 1898) p. 121. 
Pat-El has published a notable diachronic study of subordination in Aramaic, which has a different focus from the current article, namely, finite adverbial clauses, especially those whose subordinators originate in prepositions. Some discussion is devoted to purpose clauses, especially negated clauses. ${ }^{4}$ Much of Pat-El's examination is devoted to the development of the formal linkage of the subordinate clause to the matrix clause. Specifically, the study looks at the use of the reflexes of the relative particle $d \bar{t}^{-}$, written $z y-, d y$-, $d$-from OA to LA, as an element of the subordinator. Pat-El demonstrates that with various types of subordinate clauses in pre-modern Aramaic there was a growing tendency to employ $d$ - together with subordinating prepositions. ${ }^{5}$

In the section on purpose clauses that are not the object of a preposition, which is devoted mostly to negated clauses, she notes that, in contrast to OA, where 'purpose was not necessarily expressed through finite clauses, but rather through nominal constructions', 'finite purpose clauses in later dialects were introduced by the relative particle $d$ - like most adverbial subordinators. ${ }^{6}$ PatEl reaches the following concluding generalisation: ${ }^{7}$

The obligatory use of the relative particle for subordination is the result of another major development in Aramaic. This particle has become the normal way to mark any type of syntactic dependency, nominal or nexal [...] This process has begun in Official Aramaic mostly in the nominal system, but spread to all syntactic positions thereafter. In Official Aramaic, and in the dialects following it, the relative particle is used as a marker of any non-matrix sentence, even if it was not marked formally as dependent in Proto-Aramaic.

The widespread use of asyndetic linking of finite direct object complements and purpose clauses in WNA is at odds with Pat-El's conclusion. It is this issue that the present article seeks to investigate.

One possibility is that language contact, namely, with Arabic, is responsible for the unexpected lack of a reflex of $d$ - and the common use of asyndesis in WNA. Arabic lexical borrowings in WNA are numerous, consisting of both lexemes and calques, ${ }^{8}$ and wNA also exhibits Arabic syntactic influence. ${ }^{9}$

4 Pat-El, Studies, pp. 21-88.

5 See her conclusions in Pat-El, Studies, pp. 142, 195.

6 Pat-El, Studies, pp. 34-46, especially 34-35.

7 Pat-El, Studies, p. 195.

8 W. Arnold and P. Behnstedt, Arabisch-Aramäische Sprachbeziehungen im Qalamūn (Syrien) (Semitica Viva, 8, Wiesbaden: Harrassowitz, 1993) pp. 61-64.

9 C. Correll, Untersuchungen zur Syntax der Neuwestaramäischen Dialekte des Antilibanon 
In his syntactic analysis, Christoph Correll devotes a section to Arabic influence on WNA syntax in connection with its historical development. ${ }^{10}$ Notably, the section begins with the following reservation: 'unfortunately, there is a great deficiency in comprehensive syntactic studies of the various forms of older Aramaic. The most exhaustive treatment by far is still that of Syriac', which Correll defines as an eastern variety of Aramaic, and not a direct forerunner of WNA. ${ }^{11}$ Nonetheless, on the basis of Syriac, Correll suggests that asyndetic direct object clauses and purpose clauses are not necessarily the result of contact with SARB. Rather, he writes, 'asyndesis, such as with noun clauses, can equally be established as Aramaic'.12

The present article aims to elucidate the historical background of the morphosyntax of WNA direct object complement clauses and purpose clauses, by examining a wide range of Aramaic dialects. Despite important strides in the study of Aramaic morphosyntax in recent years, including that of Western Late Aramaic, ${ }^{13}$ the general study of complementation strategies, clause linking, and their historical development in Aramaic is still lacking. Therefore, the current study goes beyond the examination of formal clause linking at various stages of Aramaic, to include a number of other morphosyntactic parameters. This wider framework includes the examination of the form of the dependent verb - which besides the infinitive, may be qtal, yiqtol, or the active participle-and how the verb form relates to tense-aspect-mood (TAM). Coreferentiality of the subject of the main verb with the subject of the dependent verb is also examined as a determinant of the choice of the dependent verb form.

For a full comparative study, the following Aramaic varieties were examined: the OA inscriptions of Sefire, Official Egyptian Aramaic, Biblical Aramaic, Qumran Aramaic, the three Western Late Aramaic varieties_Christian Palestinian

(Abhandlung für die Kunde des Morgenlandes, XLIV, 4, Wiesbaden: Deutsche morgenländische Gesellschaft, 1978) pp. 114-129; W. Arnold, 'Relative Clauses in Western NeoAramaic', in J.C.E. Watson and Jan Retsö (eds.), Relative Clauses and Genitive Constructions in Semitic (Jss Supplement, 25, Oxford: Oxford University, 20o9) pp. 65-68.

10 Correll, Untersuchungen, pp. 135-151.

11 Correll, Untersuchungen, p. 137 (my translation).

12 Correll, Untersuchungen, p. 147 (my translation), and n. 284 there.

13 J. Lund, A Descriptive Syntax of the Non-Translational Passages according to Codex Neophyti 1 (unpublished M.A. thesis, Hebrew University of Jerusalem, 1981) (in Hebrew); C. Stadel, The Morphosyntax of Samaritan Aramaic (Jerusalem: Mosad Bialik, 2013) (in Hebrew); I.J. Bunis, The Morphosyntax of Jewish Palestinian Aramaic from the Byzantine Period (unpublished Ph.D. dissertation, Hebrew University of Jerusalem, 2018) (in Hebrew). 
Aramaic (CPA), Jewish Palestinian Aramaic (JPA), and Samaritan Aramaic (sA) - and Syriac. The rationale for including Syriac is that it does not belong to the western branch of Late Aramaic, and thus adds a wider perspective to the situation in Late Aramaic. Scholars debate whether to classify Syriac as a dialect of Late Eastern Aramaic or, alternatively, as belonging to a separate Central Late Aramaic branch, due to some shared features with Western Aramaic. ${ }^{14}$ Aaron M. Butts suggests that such shared features are likely the result of language contact between Syriac and geographically neighbouring dialects, and not due to Syriac originating in the same proto-language as the Western Late Aramaic dialects. ${ }^{15}$ Lastly, WNA was examined, and a final comparative section looks at SARB to assess the likelihood and extent of its influence on WNA.

Before commencing, a theoretical framework for the analysis is presented. The current article adopts a parametric approach, based mainly on traditional parameters, as presented by Volker Gast and Holger Diessel. ${ }^{16}$ Within this framework, a clause is defined as 'a pairing of a predicate and a (potentially empty) set of arguments. ${ }^{17}$ The two types of clauses under discussion here both appear as parts of 'complex sentences', i.e., sentences with more than one clause. ${ }^{18}$ Three general parameters are pertinent to the analysis of clauses that are combined with another constituent: ${ }^{19}$ (i) the relation of dependency, (ii) the element to which the clause is attached, and (iii) the morphosyntax of the attached clause itself.

With respect to parameter (i) — the relation of dependency-all constructions of direct object clauses and purpose clauses presented in the current analysis are defined in the present article as subordinate. This follows Gast and Diessel, who define a subordinate clause as dependent on another constituent syntactically, semantically, or prosodically. ${ }^{20}$ The clauses discussed in the present article all meet the criteria of semantic dependency. Most also show syntactic dependency. With the exception of WNA and SARB, for which recordings of live speakers are available, the prosody of the examined constructions

14 For a discussion of this issue, see A.M. Butts, 'The Classical Syriac Language', in D. King (ed.), The Syriac World (New York: Routledge, 2019) pp. 222-242 (224-225).

15 Butts, 'Classical Syriac', pp. 224-225.

16 See V. Gast and H. Diessel, 'The Typology of Clause Linkage: Status Quo, Challenges, Prospects', in V. Gast and H. Diessel (eds.), Clause Linkage in Cross-Linguistic Perspective: Data-Driven Approaches to Cross-Clausal Syntax (Trends in Linguistics. Studies and Monographs, 249, Berlin: Walter de Gruyter, 2012) pp. 1-36 (2-7).

17 Gast and Diessel, 'Clause Linkage', p. 3.

18 Gast and Diessel, 'Clause Linkage', p. 3.

19 Gast and Diessel, 'Clause Linkage', pp. 4-7.

20 Gast and Diessel, 'Clause Linkage', pp. 4-5. 
is unknown. Dependency may be marked explicitly by a coordinator or subordinator (i.e., 'syndetic' linking), or may not be marked (i.e., 'asyndetic' linking). ${ }^{21}$ Finally, the constructions functioning as direct object complement clauses all fill the complement slot of a governing predicate, whereas purpose clauses serve as adjuncts.

Regarding parameter (ii) - the element to which the clauses are attachedit is a predicate with which all the constructions discussed in the current article are combined. In most cases the governing predicate is a verb form, though cases of adjectival predicates are also discussed. When taking a complement, such a predicate is termed 'complement taking predicate' (СТ P) in the present article. $^{22}$

With respect to parameter (iii) — the morphosyntactic characteristics of the attached clause-the traditional distinction is between clauses with finite verbs, which exhibit tense inflection and subject agreement, and non-finite verbs that do not. More modern approaches see finiteness as gradual, and a characteristic of clauses, not verbs. In this view, declarative main clauses serve as a 'standard of comparison.' ${ }^{23}$ Other types of clauses may differ from this standard in the morphosyntactic features they encode, such as the realisation of arguments and TAM categories.

Based on this approach, the subordinate clauses examined in the present article are divided into three types according to the finiteness of their verbs: (i) Non-finite, i.e., infinitival clauses, (ii) Finite, whose verbs are in the qtal or yiqtol conjugations, and (iii) From Late Aramaic on, the subordinate participial clause, which is more finite than the infinitive, in view of its inflection for number and gender. In WNA, participles also acquire inflection for person in the form of obligatory prefixes.

Except for WNA, I limit the analysis of purpose clauses to those that are not linked to the main clause by 'grammatical morphemes with lexical content (e.g., English before, when, if )', but rather by elements 'with no lexical meaning, ${ }^{24}$ as well as to asyndetic purpose clauses. In Aramaic, such purpose clauses are formally identical to direct object complement clauses. Linking elements

\footnotetext{
$21 \quad$ Gast and Diessel, 'Clause Linkage', p. 5.

22 M. Noonan, 'Complementation', in T. Shopen (ed.), Language Typology and Syntactic Description. II. Complex Constructions (Cambridge: Cambridge University Press, 2nd edn, 2007) pp. 52-150 (53).

23 Gast and Diessel, 'Clause Linkage', p. 6.

24 S.A. Thompson, R.E. Longacre, and S.J.J. Hwang, 'Adverbial Clauses', in Shopen (ed.), Language Typology and Syntactic Description. II. Complex Constructions, pp. 237-300 (238).
} 
that lack lexical content include $\underline{d} \bar{\imath}^{-}$and its later reflexes, $d \bar{\imath}^{-}, d-$, for finite purpose clauses, and $l$-for infinitival purpose clauses, which as I show, lacks lexical content in many of the Aramaic dialects. I term infinitive clauses linked by $l-$ 'l-infinitive clauses'.

Some of the constructions discussed may be considered serial verb constructions (svCs), for which the research literature reflects varying definitions. According to Alexandra Aikhenvald, for instance,

A serial verb construction (SVC) is a sequence of verbs which act together as a single predicate, without any overt marker of coordination, subordination, or syntactic dependency of any other sort. Serial verb constructions describe what is conceptualized as a single event. They are monoclausal; their intonational properties are the same as those of a monoverbal clause, and they have just one tense, aspect, and polarity value. ${ }^{25}$ [...] They do not constitute a single grammatical category. They show semantic and functional similarities to multiclausal and subordinating constructions in non-serializing languages. ${ }^{26}[\ldots]$ Their components may always be contiguous $[\ldots]$ or they may be interruptible by other constituents. ${ }^{27}$

Aikhenvald's broad definition of svc s combines formal and semantic criteria. Functionally, svcs parallel both 'multiclausal' (including coordination) ${ }^{28}$ and subordinating constructions. Formally, they must lack an explicit linking element. Otherwise, serial verbs do not necessarily share the subject argument, ${ }^{29}$ and a negator may appear once in the svc, or with each verb. ${ }^{30}$ This definition partially overlaps with Gast and Diessel's asyndetic clause combining, presented above. Aikhnevald's definition also differs from Noonan's, which views svc s as necessarily sharing the same subject, and only allowing one negator. ${ }^{31}$

In light of such definitions of svc s, it is not surprising that also among Semitists, the very use of the term is disputed, ${ }^{32}$ and is used differently from both

25 A.Y. Aikhenvald, 'Serial Verb Constructions in Typological Perspective', in A.Y. Aikhenvald and R.M.W. Dixon (eds.), Serial Verb Constructions: A Cross-Linguistic Typology (Explorations in Linguistic Typology, Oxford: Oxford University Press, 2006) pp. 1-68 (1).

26 Aikhenvald, 'Serial Verb Constructions', pp. 2-3.

27 Aikhenvald, 'Serial Verb Constructions', p. 3.

28 See Aikhenvald, 'Serial Verb Constructions', p. 6.

29 Aikhenvald, 'Serial Verb Constructions', pp. 12-18.

30 Aikhenvald, 'Serial Verb Constructions', pp. 8-10.

31 Noonan, 'Complementation', p. 87.

32 See L. Edzard, 'The Finite-Infinite Dichotomy in a Comparative Semitic Perspective', in 
Aikhenvald and Noonan. The strict criterion of no overt linking element is not adopted by Lutz Edzard, for instance, who uses the term svc also for constructions with an overt coordinator. ${ }^{33}$ Moreover, Aikhenvald's definition includes intonational properties, which for the most part are unavailable for the premodern Aramaic dialects discussed below.

Therefore, in the present article, constructions loosely fitting these definitions will be termed SVCs, not for the aim of precisely placing them in a cross-linguistic setting, but rather for elucidating the historical development of constructions used as direct object complements and purpose clauses in WNA.

2

\section{Direct Object Clauses and Purpose Clauses in Aramaic Prior} to the Late Aramaic Stage

Aramaic dialects that precede the LA stage attest several constructions of direct object clauses and purpose clauses, involving both infinitive and finite clauses.

\subsection{Infinitive Clauses}

In the recorded occurrences prior to LA, infinitive clauses in the function of direct object and purpose adverbials invariably begin with the element $l$ - This element might originally have had semantic content, expressing a 'sense of direction, of purpose. ${ }^{34}$ Already in OA, however, its use in contexts where purpose is not expressed reflects the loss of this semantic content, such as with direct object complements, with which it merely functions as a subordinator. By OFEA, even infinitive clauses functioning as subjects appear with $l$, though not obligatorily. ${ }^{35}$ Infinitival direct object complements do not appear to be restricted by the type of matrix predicate. ${ }^{36}$ In OA and OFEA they are found with the verbs of ability khl/ykl 'be able' (Ex 1), and volitional șby 'desire' (Ex 2). Embedded infinitives are restricted in that their subject must be co-referential with that of the matrix clause, except with manipulative matrix verbs (Exs 7-8).

A. Amha, R. Meyer, and Y. Treis, (eds.), Explorations in Ethiopian Linguistics: Complex Predicates, Finiteness and Interrogativity (Abhandlungen für die Kunde des Morgenlandes, 91, Wiesbaden: Harrassowitz, 2014) pp. 205-223 (216).

33 Edzard, 'Finite-Infinite Dichotomy', pp. 216-217.

34 See T. Nöldeke, Compendious Syriac Grammar, trans. J.A. Crichton (London: Williams \& Norgate, 1904) p. 223.

35 T. Muraoka and B. Porten, A Grammar of Egyptian Aramaic (HdO, 32, Brill: Leiden, 1998) p. 210.

36 See Noonan, 'Complementation', pp. 120-144. 
(1) OA, Sefire, I B $34^{37}$

l-y-khl l-prq w-l-mšlh $\quad y d$ not-3MS-able.IMPERF SUBRD-destroy.INF and-to-send.INF hand b-my byr-' in-water.cs well-DEF

'He shall not be able to destroy and raise a hand against the water of the well'.

(2) OFEA, B3.4:14 38

sby-t l-mnth

desire.PERF-2MS SUBRD-give.INF

'You desired to give'.

In BA and QA they are attested complementing these verbs, as well as inchoative šry 'begin' (Exs 3-4).

(3) BA, Ezra 5.2

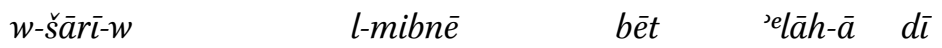

and-begin.PERF-3MPL SUBRD-build.INF house.Cs god-DEF REL

b-ìrūšlım

in-Jerusalem

'And they began to build the house of God that [was] in Jerusalem'.

(4) QA, 4Q209 $\mathrm{iii}^{39}$

mšrh-Ø l-mtb l-mth

begin.PART-MS SUBRD-repeat.INF to-come.INF

'He begins to come again'.

Additionally, the $l$-infinitive clause is used in OA (Ex 5) and of EA (Ex 6) as a purpose adverbial. ${ }^{40}$ In this use as well, the subjects of the matrix and embedded clauses co-refer.

37 J.A. Fitzmyer, The Aramaic Inscriptions of Sefîre (Rome: Pontifical Biblical Institute, 1967) p. 211.

38 Muraoka and Porten, Egyptian, p. 208.

39 T. Muraoka, A Grammar of Qumran Aramaic (ANES, 38, Leuven: Peeters, 2011) p. 18o.

40 And later in BA, for instance Dan. 2.14. 
(5) OA, Sefire I A $13^{41}$

pqh-w lyn-y-km l-hzyh 'dy br g'yh

open.IMP-2MPL eye-PL.CS-2MPL to-see.INF treaty.CS son.CS PN

'Open your eyes to see the treaty of the son of PN'.

(6) OFEA, C2.1:15 $5^{42}$

'zl-w l'rq-h zy ddrš l-m'bd qrb

go.PERF-3MPL toward-3MS REL PN to-do.INF battle

'They went toward PN to do battle'.

In all these varieties, the embedded infinitive is used when its subject is coreferential with the subject of the matrix clause. Moreover, in BA and QA (with the exception of Ex 19 below), embedded infinitive clauses are the only construction that is attested when the subject of the embedded clause is coreferential with that of the matrix clause. ${ }^{43}$

Nonetheless, OFEA (Ex 7), BA (Ex 8), and QA all attest to a category of infinitive clause in the role of direct object, in which, in contrast to Exs 1-6, the embedded and matrix subjects are not co-referential, namely, clauses that complement manipulative predicates. ${ }^{44}$ Here the subject of the direct object clause is co-referential with an object of the matrix clause:

(7) OFEA, B2.2:645

$t^{\prime} n-w-k \quad l-y \quad m w m$ 'h l-mwm'

impose.PERF-3MPL-DO.2MS to-1S oath SUBRD-swear.INF

'They imposed on you to take [= that you take] an oath for me'.

(8) BA, Dan. 3.20

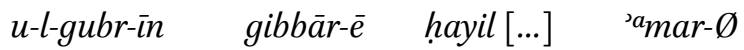

and-to-man-PL great.PL-Cs strength [...] say.PERF-3MS

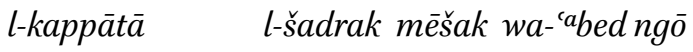

SUBRD-bind.INF to- $\mathrm{PN}_{1} \quad \mathrm{PN}_{2}$ and- $\mathrm{PN}_{3}$

'And he told men of great strength $[\ldots]$ to bind $\mathrm{PN}_{1}, \mathrm{PN}_{2}$, and $\mathrm{PN}_{3}$ '.

\footnotetext{
41 Fitzmyer, Sefîre, p. 212.

42 Muraoka and Porten, Egyptian, p. 234.

43 Muraoka, Qumran, pp. 180-181 ( $\$ 56 \mathrm{~h})$.

44 See Noonan, 'Complementation', pp. 136-137.

45 Muraoka and Porten, Egyptian, p. 208.
} 


\subsection{Finite Direct Object and Adverbial Clauses}

Finite clauses in these two functions in pre-LA are either subordinated syndetically or are linked asyndetically with no overt subordinator. Specifically, finite clauses that parallel the infinitive clauses of $\S 2.1$ are introduced by the complementiser $z y$-/dy- when syndetic. ${ }^{46}$

\subsubsection{Syndetic Finite Embedded Clauses}

Syndetically embedded direct object or adverbial clauses are not attested in OA or OFEA with one possible exception. ${ }^{47}$ By contrast, in BA (Exs 9, 11-12) and QA (Ex 10) finite clauses in both functions are all syndetic, ${ }^{48}$ except for one occurrence in the latter (Ex 19 below). These two varieties show a complementary distribution: infinitive clauses are used when the subjects of the matrix and embedded clauses co-refer (except for complements of manipulative verbs [Exs 7-8]), and finite clauses are used when the subjects of the matrix and embedded clauses do not co-refer (Exs 9-12). In BA and QA, the finite construction complements volitional b'y 'ask, desire'.

(9) BA, Dan. 2.16

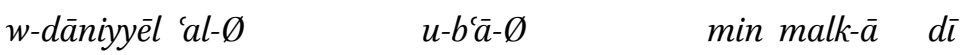

and-PN enter.PERF-3MS and-ask.PERF-3MS of king-DEF SUBRD

zmān yi-ntin $\quad l-\bar{e}$

time 3MS-give.IMPERF to-3MS

'And $\mathrm{PN}_{1}$ entered and asked of the $\mathrm{king}_{2}$ that he $\mathrm{e}_{2}$ give him $\mathrm{i}_{1}$ time'.

(10) $1 \mathrm{Q} 2 \mathrm{O}, \mathrm{XX}, 21$

$b^{\prime \prime}-\varnothing \quad m n-y d y \quad$ '-th

ask.PERF-3MS of-1S SUBRD 1SG-come.IMPERF

'He asked of me that I come'.

In BA the same embedded construction is attested in the function of a purpose clause-again, only when its subject does not co-refer with that of the matrix clause:

46 For other types of clauses, the inherited subordinators ' $a d, k \grave{l}$ are also attested; see Pat-El, Studies, pp. 28-46.

47 Muraoka and Porten, Egyptian, p. 26o. See also R. Degen, Altaramäische Grammatik der Inschriften des 10.-8. Jh. v. Chr. (Abhandlungen für die Kunde des Morgenlandes, XxxvıII, 3, Wiesbaden: F. Steiner, 1969) pp. 109-113.

48 See also Muraoka and Porten, Egyptian, p. 222, n. 95. 
(11) BA, Dan. 2.17-18

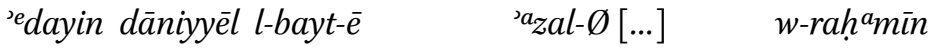

then PN to-house.Cs-3MS go.PERF-3MS [...] and-mercy

l-mibcē... di la $y$-hōbd-ūn dāniyyè

SUBRD-ask.INF [...] SUBRD not 3 M-slay.IMPERF-PL PN

$w$-habr-ō-hì

and-friend-PL.CS-3MS

'Then PN went home $[\ldots]$ and to ask for mercy $[. .$.$] so that they would not$ slay PN and his friends'.

(12) BA, Dan. 4.3

[...] l-han'ālā qādām-ay l-kōl hakkim-ē bābel

[...] SUBRD-bring.in.INF before-1s to-all wise.man-PL.cs Babylonia

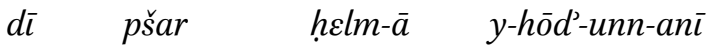

SUBRD meaning.CS dream-DEF 3M-Say.IMPERF-PL-DO.1S

'[...] to bring before me all the wise men of Babylonia, in order that they tell me the meaning of the dream'.

The use of the non-past yiqtol form as the embedded verb both to complement volitional b'y (Exs 9-10) and in purpose clauses (Exs 11-12) is no doubt connected to the volitional, or more generally the irrealis modality, of both of these types of clauses. The form used in BA and QA in such embedded clauses is the indicative, or 'long imperfect' (Exs 11-12), which is still functionally distinguished from the morphologically short yiqtol form in these varieties. ${ }^{49}$

Unlike BA and QA, in OA and OFEA, asyndesis is the norm, as reflected in over fifty asyndetic finite constructions in the role of direct object complement (Exs 13-21). Three apparent occurrences of asyndetic finite constructions expressing purpose were found in OFEA (Exs 22-23 below).

Within OA and OFEA, complementation strategies that involve finite constructions for expressing the direct object reflect two morphosyntactic patterns. The distribution of the two patterns shows a dependence on the CTP. The first pattern appears with the verbs of ability $y k l / k h l$, and perhaps with

49 On the active modal distinction between the long and short imperfect forms in QA, see H. Gzella, Tempus, Aspekt und Modalität im Reichsaramäischen (Veröffentlichungen der Orientalischen Kommission, 48, Wiesbaden: Harrassowitz, 2004) p. 305, 7.3.3; Muraoka, Qumran, p. 101. 
aspectual (inchoative) šry 'begin' as the CTP. These CTPs are complemented by a verb with the same tense/aspect (Exs 13-18), perhaps an instance of 'tense copying. ${ }^{50}$ This pattern may constitute a svc, especially by Aikhenvald's broad definition (see end of $\S 1$ above) This pattern persists in Syriac and partially in WLA. A different pattern occurs in volitional contexts. In OFEA, when the complement taking verb is volitional, the form of the complement verb is indicative (i.e., long) yiqtol, regardless of that of the matrix verb (Exs 20-21). This same morphosyntactic pattern is found with adverbial clauses of purpose (Exs 2223), which are essentially also volitional. This pattern persists in Syriac, WLA, and eventually WNA.

Two occurrences of the first pattern appear to occur in OFEA, in which both the CTPs and the complement verbs are in qtal, with khl 'able' (Ex 13) and šry (Ex 14) as the СтP s. The CтP s and complement verbs are subject co-referential. In both cases the orthography may alternatively reflect participles rather than qtal forms,${ }^{51}$ but importantly the complement verb is not in yiqtol.

(13) OFEA, B3.4:22

$w$-l' khl-n pșl-n

and-not able.PERF-1PL cleanse.PERF-1PL

'And we were not able to cleanse'.

(14) OFEA, D7.9:11

šry-n $\quad y h b-n \quad$ prs

begin.PERF-1PL give.PERF-1PL allotment

'We have begun to give out an allotment'.

The same pattern, but with both the CTP and complement verb in yiqtol, is common and is found two or three times in OA (Ex 15), and over fifty-five times in OFEA (Exs 16-18).52 These make up the vast majority of occurrences of $y k l / k h l$ taking a clausal direct object complement. The subjects of complement taking $y k l / k h l$ and the complementing verb are mostly co-referential, paralleling Ex 13 above. With respect to the marking of negation we find 'concordant marking' (i.e., on every verb $)^{53}$ in the oA inscriptions from Sefire, whereby the negative particle $l-|*| \bar{a} \mid$ is repeated with both verbs (Ex 15). ${ }^{54}$ In OFEA, we find 'single

$50 \quad$ Noonan, 'Complementation', pp. 98-10o.

$51 \quad$ Muraoka and Porten, Egyptian, pp. 255-256, 26 o.

$5^{2}$ Muraoka and Porten, Egyptian, pp. 255-256, 26 o.

53 Aikhenvald, 'Serial Verb Constructions', p. 43.

54 Fitzmyer, Sefîre, pp. 122-123, 210. 
marking' of negation (i.e., the negative particle is only found once) before the first verb (Exs 16-18).

(15) OA, Sefire 2.b:6
$p-l^{-}-k h l$
l-’-šlh
$y[d]$

then-not-1s-able.IMPERF not-1S-send.IMPERF hand

'Then I shall not be able to raise a ha[nd]'

(16) OFEA, B3.7:1455
l' '-khl
'nh 'nny '-hnșl
not 1S-able.IMPERF I PN 1S-reclaim.IMPERF
'I, PN, shall not be able to reclaim'.

Although in OFEA most occurrences of the CTP s and complementing verbs are contiguous, and agree in all grammatical categories, as in Exs 13-15, this is not obligatory. The two verbs do not appear contiguously in Exs 16-18, and in two occurrences (Exs 17-18) the subjects of the СтP and of the complement verb, as encoded by the verbal inflection, do not co-refer:

(17) OFEA, B3.9:4 $4^{56}$

l' '-khl 'nh [...] $y$-kbš-nhy

not 1S-able.IMPERF I [...] 3MS-press.IMPERF-DO.3MS slave

'I shall not be able [...] [that] he press him into slavery'.

(18) OFEA, B3.9:6 $6^{57}$

l' '-khl 'nh w-br w-brh l-y[...]

not 1s-able.IMPERF I and-son and-daughter of-1s [...]

$n-q w m$

1PL-get.up.IMPERF

'I shall not be able and [any] son or daughter of mine [...] [that] we rise'.

Muraoka also reports a single instance of an asyndetic direct object complement clause of $y k l$ 'able' in QA (Ex 19), ${ }^{58}$ as in OA and OFEA. The complement verb yšm ' is no doubt in yiqtol, but the CтP form $y k l$ may reflect either yiqtol

55 Muraoka and Porten, Egyptian, p. 255.

56 Muraoka and Porten, Egyptian, p. 256.

57 Muraoka and Porten, Egyptian, p. 256.

58 Muraoka, Qumran, p. 207. 
or an active participle. In the latter case, this would then not reflect a svc but rather the second complementation pattern, described below, typical of volitional CTPs.

(19) QA, 4Q212 1V16

$y$ - $k l \quad / y k l-\varnothing \quad y$-šm

3MS-able.IMPERF / able.PART-MS 3MS-hear.IMPERF

'He is able to hear'.

The second pattern - that of volitional verbs governing asyndetic direct object clauses - is found some six times, in OFEA, all with the matrix verb șby 'want, desire'. In all occurrences the embedded verb is in yiqtol, but the matrix verb is in qtal (Exs 20-21), ${ }^{59}$ thus paralleling the syndetic construction with $b^{c} y$ in BA and QA (Exs 9-10, $§$ 2.2.1 above). In contrast to BA and QA, though, in five of the six occurrences, the subjects of the two verbs co-refer (Ex 2O). Only in one occurrence, the subjects of the matrix and embedded verbs do not co-refer (Ex 21), as in BA and QA.

(20) OFEA, B3.8:41, B6.4:7 $7^{60}$

șby-t '-hnșl hmw

desire.PERF-1S 1S-reclaim.IMPERF DO.3MPL

'I desired to reclaim them'.

(21) OFEA, B3.7:15

l' '-khl '-mr npš-y şby-t

not 1S-able.IMPERF 1S-Say.IMPERF soul.F.CS-1S desire.PERF-3FS

'-hnșl

1S-reclaim.IMPERF

'I will not be able to say, "my soul desires that I reclaim"'.

A few examples of asyndetic purpose clauses occur in OFEA. In the few that I could locate, the subjects of the matrix and purpose clauses were not coreferential. Muraoka and Porten note a single occurrence (Ex 22), which parallels, on the one hand, $l$-infinitive purpose clauses in that variety (Exs $5^{-6}$ ), and on the other, syndetic finite purpose clauses in BA (Exs 11-12). The matrix verb in (Ex 22) is ntn 'give', in the jussive or short yiqtol form. The subordinate verb is in

59 See Muraoka and Porten, Egyptian, pp. 134-142.

6o Muraoka and Porten, Egyptian, p. 256.

61 See Muraoka and Porten, Egyptian, p. 256 n. $103^{2}$. 
yiqtol. Muraoka and Porten comment that this example is 'highly problematic'. But Ex 23, which is noted by Stanislav Segert, shows similar morphosyntax; the CTP is also in a volitional mood, namely, the imperative rather than the jussive. Furthermore, examples in Syriac (Ex 39) and WLA, especially JPA (Ex 77), reflect similar morphosyntax.

(22) OFEA, A6.11:3 $3^{62}$

$y$-ntn-w l-y '-hhsh

3M-give.JUS-PL to-1S 1S-store.IM PERF

'Let them give [it] to me [that] I may store [it]'.

(23) OFEA, A6.12:3 $3^{63}$

$w$-hwšr-w y-hyt-w l-y

and-send.IMP-2M PL 3M-bring.IMPERF-PL to-1S

'And send [so that] they bring to me'.

\section{Direct Object Clauses and Bare Adverbial Clauses in Syriac}

Syriac is a LA dialect that is not part of the western branch (see discussion in $\S 1$ above). Similarities in the morphosyntax of embedded clauses between this variety and pre-LA, as well as WLA suggest that some of the features found in LA were widespread, and perhaps retained from pre-LA. In what follows examples that are adduced without a footnote are taken from Theodor Nöldeke's grammar, using his abbreviations. ${ }^{64}$ I have included some phonologically unrealised orthographic elements in bracketed superscript, as an aid to the transcription. I employ the term 'bare clause' to signify clauses that are not linked by an element with 'lexical meaning'. 65

\subsection{Infinitive Clauses}

Syriac has retained this non-finite construction from pre-LA, and it can function as the verb form in both direct object and purpose clauses, when the subjects of the matrix and embedded clauses co-refer. Whereas in pre-LA, the preposition $l$ - is not yet an obligatory element of the infinitive ( $\$ 2.1$ above), in Syriac it is

\footnotetext{
62 Muraoka and Porten, Egyptian, pp. 256-257.

63 S. Segert, Altaramäische Grammatik (Leipzig: ve в Verlag Enzyklopädie, 1975) p. 439.

64 Nöldeke, Syriac, pp. xv-xvi.

65 Thompson et al., 'Adverbial Clauses', pp. 237-30o (238).
} 
already fixed, ${ }^{66}$ and I therefore do not consider it a separate subordinator as in pre-LA, but part of the infinitive's morphology. As a direct object, an infinitive clause can apparently complement any class of predicate, such as the Syriac verb of ability 'eškah (Ex 24), volitional șbī (Ex 25), and aspectual verbs such as šarı̀ 'begin' (Ex 26) and 'awsep 'continue' (Ex 27). As a purpose adverbial, it seems to be governed frequently by motion verbs (Ex 28$) .67$

(24) Aphr. 136:4

lā meškah-Ø lmeta $^{\left({ }^{\prime}\right)} s \bar{a} y \bar{u}$

not able.PART-Ms heal.INF.PAS

'He is not able to be healed'.

(25) Chronicle of Zuqnin, Part $2^{68}$

w-men dehlat-hōn lā șābēen $n \quad{ }^{(h)}$ wa-w lmepaq

and-from fear.Cs-3MPL not want.PART-MPL be.PERF-3MPL go.out.INF 'And because of their fear, they did not want to leave'.

(26) Jos. Styl. 24, 11

šarī- $\emptyset \ldots \quad$ Imebnā

begin.PERF-3MS ... build.INF

'He began to build'.

(27) Jul. 98, 11

w-lā 'awsep- $\emptyset \quad$ tūb lmeby-āh

and-not continue.PERF-3MS again seek.INF-DO.3FS

'And he no longer continued to seek her'.

(28) Aphr. 112:12

kad lamsalāyū 'äty-ān hwa-y

when.SUBRD pray.INF come.PART-FPL be.PERF-3FPL

'When they were coming to pray'.

$66 \quad$ Nöldeke, Syriac, pp. 224-225.

$67 \quad$ Nöldeke, Syriac, p. 224.

68 Based upon Jean Baptiste Chabot (ed.), Chronicon Pseudo-Dionysianum vulgo dictum. I (Corpus Scriptorum Christianorum Orientalium, 91, Louvain: Secrétariat du csco, 1968), Digital Syriac Corpus, https://syriaccorpus.org/518. Websites last accessed on 24June 2021. 


\subsection{Finite Clauses}

Syriac evinces both syndetic subordination through $d$-, and asyndesis.

3.2.1 Syndetically Embedded Finite Clauses

Finite clauses embedded syndetically can function in Syriac, as in earlier BA and QA (Exs 9-10), as direct objects, when their subject does not co-refer with that of the matrix clause:

(29) Book of Steps, Memra 13: By the Same Author of 'On the Ways of the Upright'69

$y \bar{a} d^{c}-\overline{-i n} \quad d-l \bar{a} \quad s ̦ a \bar{a} b \bar{e}-n \quad d-{ }^{\left({ }^{\prime} n \bar{a} \bar{s}\right.}$

know.PART-MPL SUBRD-not wish.PART-MPL SUBRD-someone

n-abēš l-hōn

3MS-treat.badly.IMPERF to-them

'[They] know that [they] do not want anyone to treat them badly'.

But Nöldeke additionally notes that, unlike in BA and QA, a finite clause introduced by $d$ - can substitute the infinitive clause in all uses ${ }^{70}$-i.e., also when its subject does co-refer with that of the matrix clause. It is thus used as the direct object of verbs such as 'eškah 'able' (Ex 30), șbī 'desire' (Ex 31), and šarı̄ 'begin' (Ex 32$)$ when the subjects of the matrix and embedded verbs co-refer. This use appears to be rather common in Syriac. ${ }^{71}$ The embedded verb in the relevant syndetic constructions is for the most part in yiqtol.

(30) Aphr. 64:9

lā 'eškah-Ø ${ }^{(w)} \quad$ da-n-rìm-ūn-āh

not able.PERF-MPL SUBRD-3M-lift.IM PERF-PL-DO.3FS

'They were not able to lift it'.

(31) Aphr. 345:1

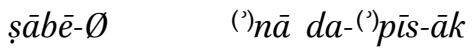

wish.PART-MS I SUBRD-1S-explain.IMPERF-DO.2MS

'I wish to explain to you'.

69 Based upon Robert Kitchen and Martien Parmentier (eds.), The Syriac Book of Steps, vol. 2 (Texts from Christian Late Antiquity, 12b, Piscataway, NJ: Gorgias Press, 2011), Digital Syriac Corpus, https://syriaccorpus.org/200.

70 Nöldeke, Syriac, p. 225.

71 Nöldeke, Syriac, p. 208. 
(32) Moes. II, 64, 1

šarī-

begin.PERF-3MS SUBRD-3MS-attack.IMPERF

'He began to attack'.

\subsubsection{Asyndetically Embedded Finite Clauses}

Syriac likewise attests to asyndetically linked finite clauses. Their morphosyntax resembles that of asyndetic clauses in OA and OFEA, i.e., their subject is often co-referential with that of the matrix clause but need not be.

As noted in $\S 2.2 .2$, verbs of ability, and possibly one occurrence of the aspectual verb šry 'begin' in OA and OFEA, appear to reflect a morphosyntactic pattern by which the embedded verbs in asyndetic clauses repeat features of the morphosyntax of the complement taking verb, especially the tense/aspect conjugation (Exs 13-18), and in OA, even the negative particle $l-/ * / \bar{a} /(\operatorname{Ex} 15) \cdot{ }^{72}$ It was also noted in $\S 1$ and $\S 2.2 .2$ that these constructions could be considered svCs. At those stages most occurrences are in yiqtol, and only two seem to be attested in qtal (Exs 13-14), but in Syriac the distribution is complete. Although Nöldeke specifically notes this unusual syntactic pattern with 'eškaḥ in the qtal form (Ex 33), ${ }^{73}$ it is in fact shared with other complement taking verbs, especially those expressing aspect, such as 'asgī 'do much' (Ex 34), hadet 'do anew, repeat' etc., ${ }^{74}$ and is also attested in yiqtol (Exs 35-36) and with the participle $(\$ 3 \cdot 3)$.

(33) Ov. 12, 19

lā 'eškhlat 'ebr-at

not able.PERF-3FS cross.PERF-3FS

'She could not cross'.

(34) Ephr. In Wright's Cat. 689a, 14

'asgi- $\varnothing \quad$ rhem- $\emptyset$

do.much.PERF-3Ms love.PERF-3MS

'He loved much'.

72 Fitzmyer, Sefîre, pp. 122-123, 210.

73 Nöldeke, Syriac, p. 275, §337b, mentioned also by Muraoka and Porten, Egyptian, p. 256, n. 1030.

74 Nöldeke, Syriac, p. 275, §337b. 
(35) Book of Steps, Memra 19: On the Discernment of the Way of Perfection ${ }^{75}$ w-man da-krīh ne-bَe men mār-an

and-who REL-weak 3Ms-ask.IMPERF of lord.CS-1PL

d-ne-škaḥ n-qabel meltā šarìrtā

SUBRD-3MS-able.IMPERF 3MS-receive.IMPERF word true

'And he who is weak, let him ask of our Lord that he be able to receive the true word'.

(36) Sim. 293

da-n-qadm-ūn ne-sq-ūn

SUBRD-3M-be.early.IMPERF-PL 3M-ascend.IMPERF-PL

'That they ascend early' (= 'that they ascend in the morning').

This pattern is not found in Syriac with šarı̄ 'begin' as the complement taking verb. However, its existence with other aspectual verbs, together with 'eškah, suggests that this is the pattern found in OFEA, not only with $k h l$ (Ex 13), but also šry (Ex 14), in the qtal conjugation.

The verb 'eškah also appears as the СтP in other patterns, namely, syndetic (Ex 30) and asyndetic subordinate constructions (Ex 37), which do not reflect serialisation, or morphological agreement between 'eškah and the embedded verb. Rather, the embedded verb is in yiqtol regardless of the form of 'eškah, which in Exs 30, 37 is qtal. The functional difference between the constructions is unclear.

(37) Homilies of Mar Jacob of Sarug76

'eškah-Ø ne-tel 'atīrāît

able.PERF-3MS 3MS-give.IMPERF generously

'He was able to give generously'.

As in OFEA (Exs 20-22), volitional complement taking verbs in Syriac do not reflect serialisation whereby the complementing verb morphologically agrees with the СтP; rather, the complementing verb appears in yiqtol even when it complements a verb in a different conjugation, such as qtal (Ex 38$)$.

75 Based upon Kitchen and Parmentier (eds.), The Syriac Book of Steps, vol. 2, Digital Syriac Corpus, https://syriaccorpus.org/206.

76 P. Bedjan and S.P. Brock (eds.), Homilies of Mar Jacob of Sarug. IV (Piscataway, NJ: Gorgias Press, 2006) p. 272:9. On the suppletion that exists in Syriac with the verb 'give', between $y h b$ in the qtal conjugation, and $n t l$ in the yiqtol conjugation, see Nöldeke, Syriac, p. 133, $\S 183$. 
(38) Homilies of Mar Jacob of Sarug77
'elū lā șba-w
$n$-ehw-ōn
dìl-āk
if not desire.PERF-3MPL $3 \mathrm{M}$-be.IMPERF-PL of-2MS
'If they did not want to be yours'.

With regard to subject co-referentiality, Nöldeke does not adduce asyndetic direct object clauses of the verb of ability 'eškah or volition șbi where the subjects of the СтР and of the complementing verb do not co-refer (compare syndetic example, Ex 29, above), as found in OFEA.

Nöldeke notes several examples of an embedded purpose clause (Ex 39), similar to Exs 22-23 from OFEA, in which the purpose clause follows a verb in a volitional mood, the imperative.

(39) Jos. St. $76,5^{78}$

apeq- $\emptyset r-\bar{a} k \quad n-m \bar{u} t$
bring.out.IMP-2MS son.CS-2MS
3MS-die.IMPERF
Bring out thy son [that] he may die'.

\subsection{Participial Clauses as Direct Objects}

A novel type of clause emerges in Syriac and LA in general, which is absent from OA, OFEA, BA, and QA, namely, the participial complement clause. This innovation has not been noticed by researchers thus far as a feature of LA. In the older varieties, the only non-finite clause that is found in this role appears to be the infinitive clause. In LA, by contrast, the apparent innovation of asyndetic participial complement clauses is widespread. This is likely part of a more general development in Aramaic since the Achaemenid period, by which participles become a prominent part of the verbal system, encroaching on the yiqtol conjugation. ${ }^{79}$

In Syriac, as in WLA ( $\$ 4.3)$, participial complement clauses are associated with specific classes of CTP s. Nöldeke notes that 'with special frequency, however, the Part. is found with "can" and "begin"'.80 In all of Nöldeke's examples with 'eškah as the СтP, both the СтP and the complement verbs are participles, and their subjects are co-referential, which as noted above may constitute serialisation:

77 P. Bedjan and S.P. Brock (eds.), Homilies of Mar Jacob of Sarug. III (Piscataway, NJ: Gorgias Press, 2006) p. 358:13.

78 Nöldeke, Syriac, p. 209, §267.

79 See Gzella, Tempus, pp. 327-329; H. Gzella, A Cultural History of Aramaic: From the Beginnings to the Advent of Islam (HdO, 111, Leiden: Brill, 2015) pp. 176-177.

8o Nöldeke, Syriac, p. 214, §272, and see other examples there. 
(40) Aphrahat, Demonstration 2: On Love ${ }^{81}$

[...] da-b-haymānūtā meškh- $\bar{a} \quad$ metqaym- $\bar{a}$

[...] that-in-faith able.PART-Fs be.established.PART-FS

Šetestā d-hānā qyāma

foundation.FS REL-this.Ms covenant.MS

'[...] For in faith can the foundation of this covenant be established'.

The same pattern is found in Syriac with aspectual verbs (Exs 41-42),82 and similarly with predicative adjectives denoting habitual aspect as the СтP, such as m'ād (Ex 43) and 'amin 'used to, accustomed to', which morphologically parallel participles, inflecting for number and gender. The verb 'asgi 'do much', for instance, is attested both in this participial morphosyntactic pattern (Ex 42) and that of qtal (Ex 34).

(41) Aphr. 458, 1

mawsp-ān metpalh-ān

continue.PART-FPL be.cultivated.PART-FPL

'They continue being cultivated'.

(42) The Syriac Book of Steps, Memra 15: On Adam's Marital Desire ${ }^{83}$

$w$-èn masgē- $\varnothing \quad$ metmakak- $\emptyset$

and-if do.much.PART-Ms humble.oneself.PART-MS

'And if he humbles himself much'.

(43) Philox 473:23

$m^{\prime} \bar{a} d-\varnothing \quad y \bar{a} h e b-\varnothing$

accustomed.ADJ-MS give.PART-MS

'Accustomed to give'.

Nöldeke's examples of subordinated participial clauses contain a few in which the CTP is a participle of volitional șbì (Ex 44), though this is apparently uncommon.

81 Based upon Jean Parisot (ed.), Aphraatis Sapientis Persae Demonstrationes (Patrologia Syriaca, 1.1, Paris: Firmin-Didot, 1894), Digital Syriac Corpus, https://syriaccorpus.org/2.

82 Nöldeke, Syriac, p. 214, § 272.

83 Based upon Kitchen and Parmentier (eds.), The Syriac Book of Steps, vol. 2, Digital Syriac Corpus, https://syriaccorpus.org/2O2. 
(44) Aphr. 153:15

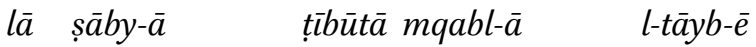

not desire.PART-FS grace accept.PART-FS to-penitent-PL

'Grace desires not to accept the penitents'.

As mentioned in $\S$ 2.2.2 and $\S 3.2 .2$ above, the participial pattern reflected in Exs 40-44 is part of a wider morphosyntactic pattern consisting of a matrix verb of ability or aspect, such as 'eškaḥ and 'asgī, which embeds a verb of the same tense/aspect. ${ }^{84}$ In pre-LA this general pattern was perhaps restricted to finite forms, whereas in LA the participial pattern emerged, replacing certain earlier uses of yiqtol (see $\S 6$ below).

A somewhat different pattern is found in Syriac, as well as in WLA, with the inchoative matrix verb šar ‘ 'begin'. This aspectual predicate also frequently embeds a participial clause, but in contrast to the previous examples, šari itself is mostly found in qtal. ${ }^{85}$ Nöldeke provides three examples (Ex 45). The same construction is exemplified once with yhab 'give' in inchoative function as the CTP (Ex 46). This construction is retained in wNA.

(45) Aphr. 210, 4

šarīw $\quad$ gāzr-īn

begin.PERF-3MPL circumcise.PART-MPL

'They began circumcising'.

(46) Sim. 342

$y a^{(h)} b-\bar{u} \quad$ àrq-ìn

give.PERF-3MPL flee.PART-MPL

'They commenced fleeing away'.

\section{$4 \quad$ Western Late Aramaic}

Generally speaking, WLA shows similar innovations to Syriac, likely reflecting general developments of the LA stage. One of these is the emergence and widespread use of participial complement clauses.

The introduction of participial complement clauses in WLA correlates with changes in the functions of the earlier constructions, namely, infinitive clauses

84 Fitzmyer, Sefîre, pp. 122-123, 210.

85 Nöldeke, Syriac, p. 214, §272. 
and finite yiqtol clauses. The use of the novel construction brings about larger functional specification of each of the embedded clause types. But WLA also shows the reverse, i.e., the decline, and even abandonment, of the use of the infinitive. The three wLA dialects show degrees of inter-dialectal variation in these developments.

\subsection{Infinitive Clauses}

Syntactically, as in earlier Aramaic and contemporaneous Syriac, an infinitive clause can serve in JPA and SA as a direct object and as an adverbial clause. Here too, embedded infinitive clauses require that their subject co-refer with that of the matrix clause, with the exception of manipulative matrix verbs (\$ 4.1.4). In CPA, the infinitive has practically gone out of use, and a finite or participial embedded clause is almost always used instead. ${ }^{86}$

In the morphosyntax of its infinitive, wLA differs both from pre-LA and Syriac with respect to the particle $l$ - as a subordinator. As in pre-LA, but unlike in Syriac, it is not a fixed morphological element of the infinitive. But in contrast to both pre-LA and Syriac, the infinitive may either be subordinated by $l$ - or occur without it, both as a direct object (Exs 47-50, 53-55, 57) and as a purpose clause (Ex 59).

Within JPA and SA, the distribution of the infinitive clause appears to be constrained by the type of matrix verb. It complements verbs of volition and, somewhat less commonly, verbs of ability, but not aspectual verbs.

4.1.1 Infinitive Clauses Complementing Verbs of Volition

In both JPA and SA, an infinitive clause is the most common clausal direct object complement of verbs of volition, when the subjects of the matrix and embedded clauses co-refer (Exs 47-50). No examples were found with volitional matrix verbs in yiqtol. ${ }^{87} \mathrm{I}$ have found around twenty occurrences of qtal forms in JPA (Ex 47), and Christian Stadel lists two in SA (Ex 48):88

(47) y. Dem. $1.3(21 \mathrm{~d})$

l' b'y-t mykwl

not want.PERF-3FS eat.INF

'She did not want to eat'.

86 See C. Müller-Kessler, Grammatik des Christlich-Palästinisch-Aramäischen (Texte und Studien zur Orientalistik, 6, Hildesheim: Olms, 1991) pp. 162-163.

87 For SA, see Stadel, Samaritan, pp. 176-177, § 215 .

88 Stadel, Samaritan, p. 177, §215. 
(48) Marqe 2.402

șb-t mpṣht-h

want.PERF-3FS save.INF-DO.3MS

'She wanted to save him'.

Infinitive clauses commonly complement volitional verbs in participial form both in JPA (Ex 49) and SA (Ex 50):

(49) y. Ber. 9.1 (13b)

lyt 't b'y-Ø mzbyn [read:mzbwn] l-k klwm

not you.Ms want.PART-Ms buy.INF to-Ms something

'Do you not want to buy anything for yourself?'

(50) Marqe 1.547

mr-h $\quad$ by-Ø $\quad$ mprq- $n h$

master.Cs-3Ms want.PART-Ms deliver.INF-DO.3Ms

'His master wants to deliver him'.

4.1.2 Infinitive Clauses Complementing Verbs of Ability

The verb of ability in all three WLA varieties is $y k l$. In general, this verb only occurs to a limited extent in the finite qtal and yiqtol conjugations when embedding a complement, in contrast to verbs of volition (§ 4.1.1, Exs 47-48). Stadel also mentions that in sA $y k l+$ infinitive is generally rare, listing altogether one example with $y k l$ in qtal (Ex 51)-influenced in his view by the Hebrew of Exod. 9.11 ${ }^{89}$ - one in yiqtol (Ex $\left.5^{2}\right)$, and three with participial $y k l$ (Ex 53).

(51) Marqe 1.693

l' $y k l-w \quad h r s ̌-y-h \quad l-m q^{\prime} m$

not able.PERF-3MPL magician-MPL-DEF SUBRD-stand.INF

'The magicians were not able to stand'.

(52) Hymns of Marqe 16.118

l' $n-y k l \quad l-m s ̌ m c$

not 1PL-able.IMPERF SUBRD-hear.INF

'We will not be able to hear'.

89 Stadel, Samaritan, p. 177, § 215 . 
(53) Marqe 1.642

ykl-yn inwn mstr w-mtqnh

able.PART-MPL they.M destroy.INF and-build.INF

'They can destroy and build'.

In JPA, I have found no occurrences of $y k l$ in yiqtol, and only a single occurrence in qtal, which possibly takes an infinitive clause as a direct object (Ex 54). The embedded form myytyth might likewise reflect myyty.PART-MS+th.DO.3ms (< mayte $y \bar{a} \underline{t}-\bar{e} h)$. In contrast to SA, participial $y k l+$ infinitive is common in JPA (Ex 55) and is an alternative to the equally common pattern of participial $y k l+$ participle (§4.3).

(54) y. Qid. $1.7(6 \mathrm{ib})$

l' $y k y l-y t \quad$ myytyt-h l-kwn

not able.IMPERF-1S give.INF-DO.3MS to-2MPL

'I could not bring him to you'.

(55) y. Sanh. $10.2(28 \mathrm{~b})$

$w$-ly-nh $y k y l-\emptyset \quad$ mysbwl

and-not-I able.PART-Ms bear.INF

'And I cannot bear [it]'.

4.1.3 Infinitive Clauses Complementing Aspectual Verbs

Unlike with verbs of ability and volition, and more generally modal verbs expressing irrealis, the use of the infinitive is very limited in WLA for complementing aspectual verbs, in contrast with BA, QA, and Syriac. In JPA, I have not found any occurrences. Stadel lists two occurrences with the matrix verb šry 'begin', specifying one of them as influenced by the Hebrew of Gen. 4.26:90

(56) Marqe 2.239

$t t^{c} \quad \check{s} r y-\emptyset \quad l-m q r y$

then begin.PERF-3MS SUBRD-read.INF

'Then he began to read'.

$90 \quad$ Stadel, Samaritan, p. 178, § 216. 


\subsubsection{Infinitive Clauses Complementing Manipulative Verbs}

As in earlier Aramaic, when the subjects of the matrix and embedded clauses are not co-referential, the embedded verb is usually finite yiqtol ( $\$$ 4.2.1, $\$ 4.2 .2)$. However, an infinitive clause is sometimes used in JPA, as in earlier Aramaic dialects $(\$ 2.1)$, to complement manipulative verbs, when the subjects of the matrix and embedded clauses do not co-refer. Here the matrix verb controls a direct object and selects it as the subject of the embedded infinitive:

(57) y. Šab. $11.5(13 b)$

r' $y s \underline{h q}$ by-r' 'l'zr mpqd- $\quad$ l-r' hwš $y h$

rabbi $\mathrm{PN}_{1}$ son.cs-rabbi $\mathrm{PN}_{2}$ order.PART-MS to-rabbi $\mathrm{PN}_{3}$

by-r' šmy [...] mbyd l-yh sl phwwt

son.cs-rabbi $\mathrm{PN}_{4}[\ldots]$ make.INF for-3Ms basket breached

'Rabbi $\mathrm{PN}_{1}$ son of rabbi $\mathrm{PN}_{2}$ orders rabbi $\mathrm{PN}_{3}$ son of rabbi $\mathrm{PN}_{4}[\ldots]$ to make a breached basket'.

\subsubsection{Infinitival Purpose Clauses}

As in pre-LA ( $\$ 2.1$, Exs 5-6) and Syriac (\$ 3.1, Ex 28), infinitive clauses function in JPA and SA as purpose clauses, either with the subordinator $l$ - (Ex 58$)$ or, much more commonly, without it (Ex 59).

(58) Marqe 1.437

știmt-w

kl $m l k-y \quad$ 'm-h l-msb

come.together.PERF-3MPL all.cs king-PL.Cs world-DEF SUBRD-take 'All the kings of the world gathered to take'.

(59) y. B. Meș. $2.4(8 \mathrm{c})$

' $l$ t mlkt-' mshy

go.in.PERF-3FS queen-DEF bathe.INF

'The queen went in to bathe'.

\subsection{Finite Embedded Clauses}

Bare finite embedded clauses are used in all three varieties of WLA, and may be syndetic, introduced by the relativiser $d$-, or asyndetic. The three dialects differ in the degree to which $d$ - is used. In CPA and JPA, constructions with and without $d$ - constitute alternatives $(\S \S 4.2 .1-4.2 .2)$. In SA, the use of $d$ - is extremely limited. ${ }^{91}$

91 See Stadel, Samaritan, pp. 114-118, 123-125. 
As in Syriac, in all three WLA dialects bare finite clauses can be used both when the matrix and embedded subjects are co-referential, and when they are not. In CPA, since infinitives are not employed to construct direct object and adverbial clauses, this is the only structural possibility. ${ }^{92}$

The use of finite embedded clauses correlates with their modality, with the three dialects showing variation in this regard. JPA reflects the narrowest use, only in volitional contexts, but not with complements of verbs of ability or aspect. In SA, they are used for irrealis, including ability, but not to complement aspectual verbs. CPA shows the widest use, with finite embedded clauses complementing verbs of volition, ability, and aspect. Finite complements of aspectual verbs in this variety appear to be limited, however, to syndetic constructions.

4.2.1 Syndetically Embedded Finite Clauses

In JPA, syndetically embedded finite clauses function as direct objects of volitional verbs (Exs 6o-61), and as adverbials of purpose (Ex 62), i.e., in volitional contexts, but not as complements of verbs of ability or aspect.

(6o) y. Ber. $2.1(4 \mathrm{~b})^{93}$

$w-r^{\prime} \quad y w h n n b^{c} y-\emptyset \quad d-y-m r-w n$

and-rabbi PN desire.PART-MS SUBRD-3M-Say.IMPERF-PL

šmw't-h $\quad m n \quad \check{s} m-y h$

saying-PL-DEF from name.Cs-3Ms

'And does rabbi Yochanan desire that they say the sayings in his name?'

(61) Gen. R. $45^{94}$

$r^{\prime} \quad y h w \check{s}^{c} \ldots b^{c} h-\emptyset \quad d-y-p r w s ̌$

rabbi PN ... want.PERF-3MS SUBRD-3MS-sail.IMPERF

'Rabbi PN ... wanted to [= that he] sail'.

(62) Gen. R. $639^{95}$

hw' msyt-Ø $\quad d-y-d^{c} \quad$ mh hynwn

he listen.PART-MS SUBRD-3MS-know.IMPERF what they 'mr-yn

say.PART-MPL

'He listens in order to know what they are saying'.

92 See Müller-Kessler, Grammatik des Christlich-Palästinisch-Aramäischen, pp. 162-163.

93 Cairo Genizah fragment Ms Heb. d. 45/3.

94 Codex Vatican 3 o.

95 Codex Vatican 3 o. 
Syndetic finite clauses are common in CPA as direct object clauses, complementing matrix verbs of volition (Ex 63), ability (Ex 64), and aspect (Ex 65), and as purpose clauses (Ex 66). Their use is nonetheless very much limited as direct object complements of aspectual predicates, which are much more often complemented by participle clauses (§4.3).

(63) Mt. $27 \cdot 17^{96}$

l-mn 'twn șby-n d-y-pn'

to-who you.MPL wish.PART-MPL SUBRD-1S-release.IMPERF

l-kwn

to-you.MPL

'Whom do you wish that I release for you?'

(64) $\mathrm{Mk} 2.4^{97}$

d-l' $\quad y^{\prime} k l-w n \quad d-y$-'qrb-wn

SUBRD-not able.PERF-3MPL SUBRD-3M-bring.close.IMPERF-PL

$y t-h$

DO-3MS

'For they were not able to bring him closer'.

(65) Lk. $9.12^{98}$

$w-y w m^{\prime} \quad \check{s} r[y]-\varnothing \quad d-y-r k w n$

and-day-DEF begin.PERF-3MS SUBRD-3MS-recline.IMPERF

'And the day began to end'.

(66) Mt. $2.2^{99}$

w-'ty-nn $\quad d-n$-sgwd $\quad l-h$

and-come.PERF-1PL SUBRD-1PL-worship.IMPERF to-3MS

'And we have come that we [= in order to] worship him'.

96 C. Müller-Kessler and M. Sokoloff, A Corpus of Christian Palestinian Aramaic. IIA. The Christian Palestinian Aramaic New Testament Version from the Early Period Gospels (Groningen: STYX, 1998) p. 39.

97 Müller-Kessler and Sokoloff, Early Period Gospels, p. 8o.

98 Müller-Kessler and Sokoloff, Early Period Gospels, p. 139; cf. the Greek, where the infinitive

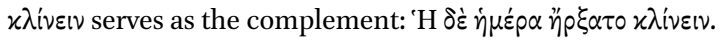

99 Müller-Kessler and Sokoloff, Early Period Gospels, p. 16. 
In sA, the use of the subordinator $d$ - for embedding finite clauses is very limited. ${ }^{100}$ In one instance it appears in a volitional context, introducing the direct object clause of a manipulative verb.

(67) Amram 16.6

$p q d-\varnothing \quad d-y$-šbt $\quad b-h \quad y s r^{\prime} l$

command.PERF-3MS SUBRD-3MS-rest.IMPERF in-3MS Israel

'He commanded that Israel rest on it [= that day]'.

The subordinator $d$ - is also found around ten times in SA at the head of finite purpose clauses, but only when negated by l'(Ex 68), never before non-negated purpose clauses.

(68) Marqe 1.325

$m s ̌ r r-\varnothing \quad l-l b-h \quad d-l^{\prime} \quad y-d h l$

strengthen.PART-MS to-heart.CS-3MS SUBRD-not 3MS-fear.IM PERF

'[God] strengthens his [= Moses'] heart so that he is not afraid'.

4.2.2 Asyndetically Embedded Finite Clauses

As noted in the previous section, whereas in JPA and CPA asyndesis is an alternative to subordination through $d$-, in SA asyndesis is pervasive with the clauses under discussion.

The same general correlations that are found within the three WLA varieties between the use of syndetic finite clauses and their modality also pertain to asyndetic finite clauses. In JPA they do not complement the verb of ability $y k l$ or aspectual predicates, but are only used volitionally, i.e., when complementing by 'desire, want' (Ex 69), or when functioning as purpose clauses (Ex 70), with embedded yiqtol forms.

(69) Gen. R. $1114^{101}$

$b$ - $t \quad n$-šwl-nk w-șdh-Ø

wish.PERF-1S 1-ask.IMPERF-DO.2MS and-be.frightening.PERF-3MS

l-y-myn-k

to-1S-from-2Ms

'I wanted to ask you but I was afraid of you'.

100 See Stadel, Samaritan, pp. 114-118, 123-125. especially p. 118.

101 Codex Vatican 6o. 
(70) Gen. R. $944^{102}$

slyq-Ø $\quad y$-šbwt b-byt-yh

go.up.PERF-3MS 3MS-celebrate.the.Sabbath.IMPERF in-home.cs-3MS

'He went up to celebrate the Sabbath in his home'.

By contrast, in SA and CPA, asyndetic finite clauses appear both in contexts of volition (Exs 71-72, 75) and ability (Exs 73-74). In sA those volitional contexts also include purpose clauses (Ex 78). In CPA this situation also parallels the much more common syndetic construction (\$4.2.1), but I could not find examples of asyndetic finite purpose clauses in this variety.

(71) Marqe 2.219

'nn b'y-n n-nks

we want.PART-MPL 1PL-slaughter.IMPERF

$w-n-d b h$

and-1PL-make.offering.IMPERF

'We want to slaughter and make an offering'.

(72) Deut. $13.8^{103}$

l' $t$-ș $b^{\prime} \quad t$-'zl ' $m-h$

not 2MS-desire.IMP 2MS-go.IMPERF with-3MS

'Do not desire to go with him'.

(73) Marqe $1.8^{104}$

$y k l-w \quad y-b d-w$

able.PERF-3MPL 3M-do.IMPERF-PL

'They were able to do'.

(74) Mk 2. $7^{105}$

mn $y k y l-\emptyset \quad y$ - ̌̌bwq sykl-n

who able.PART-MS 3 Ms-forgive.IMPERF sin-PL

'Who can forgive sins'.

102 Codex Vatican 6o.

103 C. Müller-Kessler and M. Sokoloff, A Corpus of Christian Palestinian Aramaic. I. The Christian Palestinian Aramaic Old Testament and Apocrypha Version from the Early Period (Gro-

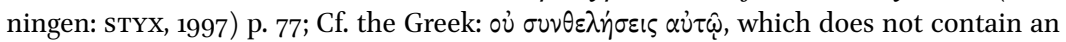
embedded direct object clause.

104 Stadel, Samaritan, §137a.

105 A.S. Lewis and M.D. Gibson (eds.), A Palestinian Syriac Lectionary:Re-Edited from Two Sinai 
With respect to subject co-referentiality, all three dialects evince embedded clauses whose subjects co-refer with that of the matrix clause (Exs 69-74), as well as embedded clauses whose subjects do not co-refer (Exs 75-78).106

CPA

(75) Lk. $1.62^{107}$

... 'wn ']bw-y [h]yk hw șb'-

... therefore father.cs-3Ms how he want.PART-MS

$y$-tqr

3Ms-be.called.IMPERF

'[They asked] his father therefore, how he wanted [his son] to be called'.

(76) y. Rosh Hash. 2.6 (58a)

'nn b'y-yn t-ythmy my-k'

we want.PART-MPL 2MS-appear.IMPERF from-here

'We want you to appear from this place'.

(77) Lev. R. $12.1^{108}$

hb-Ø l-y 'wp hhy'[read:hhw'] qist-'

give.IMP-2Ms to-1S also that.Ms xestes.Ms-DEF

$n$-šty-nyh

1S-drink.IMPERF-DO.3MS

'Give me that xestes [= measurement of wine] as well that I may drink it'.

SA

(78) Hymns of Marqe $8.37^{109}$

$y m-h \quad p l g-t \quad l-b d-y-k$

sea.MS-DEF divide.PERF-2MS for-servant-PL.CS-2MS

Mss. and from P. De Lagarde's Edition of the "Evangeliarium Hierosolymitanum" (London: Kegan Paul, Trench, Trübner, 1899) p. 139, Codex A.

106 See also, Stadel, Samaritan, $\S 126$ and $\S 128$, pp. 116-118 for a detailed description of such clauses in SA.

107 Müller-Kessler and Sokoloff, Early Period Gospels, p. 136.

108 Cairo Genizah fragment T-S C2.162.

109 Stadel, Samaritan, p. 115, §126c. 


$$
\begin{aligned}
& y \text { - } g w z-w n \quad \lg w-h \\
& \text { 3M-pass.IMPERF-PL in-3MS } \\
& \text { 'You divided the sea so that your servants would pass within it'. }
\end{aligned}
$$

In none of the WLA dialects were aspectual matrix predicates found to be complemented by asyndetic finite clauses.

\subsection{Embedded Participial Clauses}

In wLA such clauses are asyndetic and their subject is always co-referential with that of the matrix clause. They do not freely interchange with infinitive and finite clauses but specifically complement verbs of ability and aspectual predicates.

\subsubsection{Complementing Verbs of Ability}

In JPA, the specificity of the participial complement is most clear. The verb of ability $y k l$ ('able') can take a direct object clause that is either infinitival (\$ 4.1.2) or participial (Ex 79), but never finite, in contrast to volitional clauses, which take a finite yiqtol clause ( $\$ 4.2)$.

(79) y. B. Meṣ. $10.1(12 \mathrm{c})^{110}$

l' $y k y l-\varnothing \quad$ 'r'yy-h bny-

not able.PART-Ms bottom.one-DEF build.PART-MS

'The bottom one cannot build'.

The same correlation is found in SA and CPA, although in those dialects, as noted in the previous section, there is some overlap in the use of finite and participial clauses. In SA, Stadel finds thirty-one occurrences of $y k l$ 'able' embedding a participial clause (Ex 80), against fourteen occurrences embedding an asyndetic finite yiqtol clause, and five embedding infinitival clauses. ${ }^{111} \mathrm{By}$ contrast, only four occurrences are listed of the volitional verbs șby/by embedding a participle $(\mathrm{Ex} 81): 112$

(8o) Marqe 1.567

$y k l-y n \quad$ inn $b d-y n$

able.PART-MPL we do.PART-MPL

'We are able to do'.

110 Codex Escorial G-I-3.

111 Stadel, Samaritan, §185, 153.

112 Stadel, Samaritan, § 187, 154-155. 
(81) Marqe 1.603

l' șbh-Ø šm-

not want.PERF-MS hear.PART-MS to-3MPL

'He did not want to listen to them'.

In CPA, of around three hundred occurrences of $y k l$, I have found thirty-three embedding an asyndetic participial complement (Ex 82). ${ }^{113}$ This construction is not as common as the generally preferred syndetically embedded construction d-yiqtol ( $\$$ 4.2.1) but is far more common than asyndetic finite complement clauses, of which I have only found four occurrences ( $\$$ 4.2.2).

(82) Jn $3.4^{114}$

hyk $y k l-\emptyset \quad$ 'nš mtyld-Ø $\quad$ -

how able.PART-Ms man born.PART-MS and-he old-MS

'How can a man be born old?'.

The thirty-three occurrences of $y k l+$ participle in CPA contrast with volitional verbs. Out of an even larger total number of occurrences of volitional șby and b'y 'desire' as matrix verbs, I found only three occurrences, in which the embedded verb is a participle:

(83) Homily 10 2:10b-11b 115 $w-l^{\prime} \quad s \quad b y-n \quad m w d^{\prime}-y n$

and-not desire.PART-MPL admit.PART-MPL

'And they do not want to confess'.

It should be noted that in WLA, in the vast majority of occurrences of $y k l$ 'able' + participial complement clause, the matrix verb $y k l$ is also a participle. As shown in $\S 3.3$ above, this is also characteristic of the matrix verb 'eškah 'able' in Syriac. In JPA, in fact, ability CTPs that appear with a participial complement are always themselves also participial. In the other varieties, the verb $y k l$ in other conjugations, although rarely attested, can also take a participle. Stadel mentions no qtal form in SA, but I have found two examples in CPA (Ex 84). Stadel notes a single yiqtol form in SA (Ex 85), and I have found two in CPA (Ex 86):

\footnotetext{
113 Through the Comprehensive Aramaic Lexicon Project, http://cal.huc.edu/.

114 Lewis and Gibson (eds.), Lectionary, p. 8.

115 M. Sokoloff, Texts of Various Contents in Christian Palestinian Aramaic (Orientalia Lovaniensia Analecta, 235, Leuven: Peeters, 2014) p. 140.
} 
(84) Lk. $8.43^{116}$

$w$-l' $y k l-t \quad m t^{\prime} s y$-' $^{\prime} \quad m n^{\prime}$

and-not able.PERF-3Fs cure.PASS.PART-Fs from man

'And she could not be cured by a person'.

(85) Amram 11.21

l' $n$-wkl q'm-yn

not 1PL-able.IMPERF stand.PART-MPL

'We will not be able to stand'.

(86) Eph. 3.18 117

lgll d-t-ykl-wn m't-yn 'm

because SUBRD-2-able.IMPERF-MPL reach.PART-MPL with

kwl-hwn qdyš-y-'

all.CS-3MPL holy-PL-DEF

'Because you will be able to reach all of the saints'.

The pattern participial $y k l+$ embedded participle is also used in contexts expressing the past by means of hwy 'be' in qtal. I have found some five occurrences in CPA (Ex 87) and three in JPA (Ex 88). Stadel does not adduce any for SA. ${ }^{118}$

(87) Acts $25 \cdot 7^{119}$

$d-l^{\prime} \quad h w-w \quad y^{\prime} k l-y n \quad m w d^{\prime}-y n$

SUBRD-not be.PERF-MPL able.PART-MPL prove.PART-MPL

'That they could not prove'.

(88) y. Qid. 1.7 (61b)

l' $k-r^{\prime} \quad$ trpwn hwy-n' $y k y l-\emptyset \quad$ byd- $\varnothing$

not as-rabbi PN be.PERF-1S able.PART-Ms do.PART-MS

'I would not have been able to do as Rabbi PN'.

116 Lewis and Gibson, Lectionary, p. 110.

117 A.S. Lewis (ed.), A Palestinian Syriac Lectionary (Studia Sinaitica, vi, London: Cambridge University Press, 1897) p. 10.

118 Stadel, Samaritan, p. 153, §185.

119 C. Müller-Kessler and M. Sokoloff, A Corpus of Christian Palestinian Aramaic. IIв. The Christian Palestinian Aramaic New Testament Version from the Early Period Acts of the Apostles and Epistles (Groningen: STYX, 1998) p. 35. 


\subsubsection{Complementing Aspectual Predicates}

As in Syriac (\$ 3.3), participial clauses in WLA also commonly complement aspectual predicates, appearing in patterns that parallel those in Syriac, both morphosyntactically and semantically. Firstly, paralleling the Syriac constructions with the forms $m$ 'äd and 'amin 'accustomed', participial clauses in WLA also regularly complement adjectives expressing habitual aspect. In JPA, two synonymous forms are found, ylyp, and nhyg, which take a participial complement in twenty-one occurrences (Ex 89-90). The past tense is expressed, as with $y k l$, by the same pattern together with finite hwy 'be' (Ex 90). In CPA, Michael Sokoloff lists șmyd as a synonym, ${ }^{120}$ which also takes a participial complement (Ex 91).

(89) y. Qid. 3:2 (63d)

hyk $r b-k w n \quad$ nhyg- $\varnothing \quad$ byd- $\varnothing$

how master.CS-2MPL accustomed.ADJ-MS do.PART-MS

'How does your master regularly act?'

(90) y. Ta'an. $4 \cdot 7(69 \mathrm{c})^{121}$

'yn hwh-Ø ylyp-Ø 'kyl-Ø lytr' d-qwpd

if be.PERF-3MS accustomed.ADJ-MS eat.PART-MS pound REL-meat 'If he was accustomed to eat a pound of meat'.

(91) The Forty Martyrs of the Sinai Desert $3 \mathrm{~b}: 9^{122}$

smyd-Ø ' 'zl-Ø l-qly-t-hwn

accustomed.ADJ-MS go.PART-MS to-cell-PL.CS-their

'Accustomed to go to their cells'.

Another verb that tends strongly towards complementation by a participle in WLA, just as in Syriac, is inchoative šry 'begin' in the D-stem. In contrast to $y k l$ and the other aspectual predicates, this verb takes a participial clause, even though it is mostly attested in qtal, as in Syriac (Exs 45-46). In JPA, all thirty or so occurrences of šry that I have found are complemented by a participle (Ex 92). In SA, Stadel reports twelve occurrences of šry + participle, against six of

120 M. Sokoloff, A Dictionary of Christian Palestinian Aramaic (Orientalia Lovaniensia Analecta, 234, Leuven: Peeters, 2014) p. 356b.

121 Genizah fragment Ms. Heb. e. 74/39.

122 C. Müller-Kessler and M. Sokoloff, A Corpus of Christian Palestinian Aramaic. III. The Forty Martyrs of the Sinai Desert, Eulogios, the Stone-Cutter and Anastasia (Groningen: STYX, 1996) p. 11 . 
šry + infinitive. ${ }^{123}$ In CPA, I have found around seventy occurrences of šry + participle (Ex 93), but only some four occurrences of the alternative construction šry $+d$-yiqtol, despite the latter otherwise being the most common construction of embedded clauses in that dialect.

(92) y. Sanh. $2.1(19 d-20 a)^{124}$

šry- $\varnothing \quad t p h-\emptyset \quad b-h d h \quad y d-h$

begin.PERF-3MS clap.PART-MS with-one hand.CS-3MS

'He began clapping with one hand'.

(93) Job $6.4^{125}$

kd 'n' mšr'-

when I begin.PART-MS speak.PART-MS they obstruct.PART-MPL

l-y

to-1S

'When I begin to speak, they obstruct me'. Neo-Aramaic

An analysis of subordination in WNA is provided by Correll. ${ }^{126}$ An overview of his description of direct object and adverbial clauses is given below, reorganised according to the verb form within the clause, and the manner of subordination, in keeping with the analysis throughout the current article. The abbreviations for the textual sources are taken from Correll. ${ }^{127}$

\subsection{Embedded Infinitive Clauses}

Verbal nouns in WNA rarely if ever function as verb phrases, and thus do not form embedded infinitive clauses. In this WNA closely resembles CPA, but contrasts with the other varieties of earlier Aramaic.

123 Stadel, Samaritan, p. 154, §186.

124 Cairo Genizah fragment T-S 12.211.

125 Müller-Kessler and Sokoloff, Old Testament, p. 109.

126 See Correll, Untersuchungen, pp. 114-129; Arnold, 'Relative Clauses in Western NeoAramaic', pp. 65-68.

127 Correll, Untersuchungen, pp. viii-ix, xvii. 


\subsection{Embedded Finite Clauses}

The imperfect yiqtol forms in WNA have developed so that they express general irrealis modality. ${ }^{128}$ In WNA, this use of yiqtol includes volitional complements (Exs 94-95), purpose clauses (Exs 99-101), and complements of verbs of ability (Ex 96), ${ }^{129}$ regardless of the form of the CTP. In these uses of yiqtol, wNA parallels the WLA dialects, especially SA and CPA, as well as Syriac. By contrast, as in WLA, especially JPA, yiqtol does not complement aspectual verbs in WNA (Exs 102-104, § 4.3 below).

(94) Ma'lūla, Ps 91,15

$\check{c}-b \bar{c} i-\emptyset \quad n-a h k_{\bar{e}}-x \quad h k \bar{c} y \underline{t} a$

2-desire.PART-MS 1-tell.IRR-IO.2MS story

'Would you like that I tell you a story' [= 'would you like me to tell you a story'].

(95) Bax'a, Св IV

hküumća Ø-ṭlïb-a minn-Ø inn-i n-'ammir-

government 3 -request.PERF-FS of-1S SUBRD-1S 1-build.IRR-INDF

matrasća

school

'The government had requested of me that I build a school'.

(96) Ğubb`adīn ${ }^{130}$

lōfaš aqtr-it $\quad n$-ūsub-Ø nofšta bnawp

no.more able.PRET-1S 1-take.IRR-INDF breath at.all

'I was no longer able to take any breath'.

With respect to formal subordination, direct object clauses and purpose clauses may both be either syndetic or asyndetic. With syndetic direct object clauses and purpose clauses, however, reflexes of the older Aramaic subordinator $d$ are never used. The subordinators used with these syndetic clauses are almost exclusively forms borrowed from Arabic. In this respect, direct object and purpose clauses in WNA contrast with relative clauses (Ex 97) and genitive constructions, in which $c^{i-}$, $c i^{-}$-, $t i$-, all reflexes of older Aramaic $d-$, are still used:131

\footnotetext{
128 Correll, Untersuchungen, pp. 50-56, 114.

129 Correll, Untersuchungen, pp. 50-56, 114, especially 52, 114 .

130 Correll, Untersuchungen, p. 178:3.

131 Correll, Untersuchungen, pp. 8, 117-118.
} 
(97) Bax'a ${ }^{132}$

fțūra ći l-ēh ći wōb 'immay-nah

breakfast REL to-1PL REL be.PRET with-1PL

'Our breakfast, which was with us'.

The distribution of the historical Aramaic subordinator $d$ - that is found in WNA is also attested in earlier Western Aramaic, in the LA dialect of SA. In SA, $d$ - is used in the same two functions as in WNA, namely, with relative clauses (Ex 98 ) and genitive constructions, ${ }^{133}$ but not with finite direct object clauses, or purpose clauses $(\S 4.2 .1)$.

(98) Marqe, book I ${ }^{134}$

lb-h $\quad d-l$ mhymn- $\varnothing \quad b-k l \quad$ 'wbd-y-k

heart-DEF REL-not believe.PART-MS in-all.cs deed-PL.CS-2MS

'The heart that does not believe in all of your deeds'.

In light of this distribution of $d$-in SA, a wLA dialect, it is possible that a similar distribution of $d$ - also existed in the related WLA forerunners of WNA, before coming into contact with Arabic. This may explain why wNA borrowed Arabic subordinators where it had none, i.e., with finite direct object and purpose clauses, but did not borrow the SARB complementiser 'illi used for relative clauses, since Aramaic $d$ - was still in use with that construction.

Direct object clauses (but not purpose clauses) are defined by Correll as noun clauses (Substantivsätze) 'which parallel [...] "that” (daß) clauses'.135 They are usually asyndetic (Exs 94, 96), but may be syndetically subordinated by inni/innu (Ex 95), nkōn, $\underline{d} \bar{o} b$, or lōb, which is most common. The inflected forms inni/innu, as well as the non-inflected $n k \bar{n} n$ (< in kān 'if was'), are borrowings from Arabic, and $\underline{d} \bar{o} b$ might be a calque of Arabic in kān, consisting of the Aramaic relative particle $\underline{d}\left(<{ }^{*} d-\right)+\bar{o} b$ 'was'.136 The same might hold for $l \bar{o} b$,

132 W. Arnold, Das Neuwestamäische. I. Texte aus Bax'a (Semitica Viva, 4, Wiesbaden: Harrassowitz, 1989) p. 200:40.

133 See Stadel, Samaritan, pp. 46-55, 76-77.

134 A. Tal, The Ark of Marqe: Edition, Translation, Commentary (Studia Judaica, 92, Studia Samaritana, 9, Berlin: De Gruyter, 2019) book I, p. 6o:7.

135 Correll, Untersuchungen, pp. 114-115, translation mine.

136 A. Spitaler, Grammatik des neuaramäischen Dialekts von Ma'ūla (Antilibanon) (Abhandlungen für die Kunde des Morgenlandes, XxıII, 1, Leipzig: Brockhaus, 1938) pp. 134-135, 139; W. Arnold, Das Neuwestamäische. v. Grammatik (Semitica Viva, 4, Wiesbaden: Harrassowitz, 1990) p. 399. 
which instead of * $d$ - features $l$-, which has widely replaced the subordinating particle * $d$ - in WNA.

Purpose clauses are commonly subordinated by the Arabic-origin prepositions (het)ta (Ex 99), lahatta, and miššon 'in order'. However, they may also take the form of bare asyndetic clauses, especially when the main verb is a motion verb (Exs 100-101).137

(99) Maclūla, PS 26,32

ayți-l-lax nawbța hetta či-ḍuk

bring.PERF-1S-IO.2MS music in.order 2MS-laugh.IRR

'I brought you music so that you would laugh'.

(100) Bax'a, Св XIV,29

$\emptyset$-ōty-in $\quad y$-zubn-un- $\emptyset \quad \dot{g} a \underline{d}$ - $y-\bar{o}$

3-come.PART-MPL 3-buy.IRR-MPL-INDF billy.goat-PL

'They come to buy billy goats'.

(101) Maclūla138

šattr-Ø-il hars-ōy-e y-ayt-un-na

send.PERF-3MS-DEF guard-PL.CS-3MS 3M-bring.IRR-PL-DO.3FS

'He sent his guards to bring her'.

\subsection{Embedded Participial Clauses}

In contrast to yiqtol, the participle in WNA is associated with non-past realis, or indicative modality. ${ }^{139}$ In embedded clauses, it appears in what Correll defines as general adverbial clauses ('allgemeine Umstandssätze'). He notes that these clauses complement a specific list of complement taking verbs but does not classify them: ismer (< Arabic mrr, tenth stem), isqel, čmm (IV, < Arabic tmm),

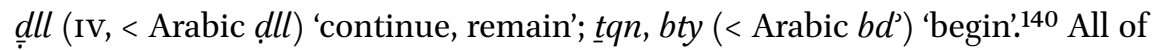
these verbs, though, are aspectual, and in particular habitual, continuous/progressive, and inchoative. Correll also notes that they specifically appear in perfect qtal (Exs 102-103) and participial (Ex 104) forms.

137 Correll, Untersuchungen, pp. 119-120.

138 W. Arnold, Das Neuwestamäische. Iv. Orale Literatur aus Ma'lūla (Semitica Viva, 4, Wiesbaden: Harrassowitz, 1991) p. 18:19.

139 Correll, Untersuchungen, pp. 56-63.

140 Correll, Untersuchungen, pp. 127-129. 
(102) Bax'a, СB, IX, 11

tiqn-innaḥ ni-mrōğ-in menn-i

begin.PERF-1PL 1-vomit.PART-MPL from-3MS

'We began vomiting from it'.

(103) Bax'a, СB X,12

ōćim- Ø Ø-qațl-il-lun laḥatta

continue.PERF-3M 3-beat.PART-MPL-DO.3MPL until

ahlk-un-nun

annihilate.PERF-3MPL-DO.3MPL

'They continued beating them until they annihilated them'.

(104) Ma'lūla, Ps 85,9

raxša $\quad$-mōdel- $\emptyset \quad \emptyset$-sōqeț-

horse.ms 3 -continue.PART-MS 3 -fall.PART-Ms

'The horse[pack] continues falling'.

A comparison between WNA and LA, especially WLA, in these types of clauses reveals striking parallels. Aspectual, especially habitual, continuous/progressive, and inchoative, СтPs take participial direct object complement clauses, and not yiqtol forms.

\section{The Impact of Language Contact between Syrian Arabic and Western Neo-Aramaic}

This comparative section aims to illuminate the degree of similarity and difference between WNA and SARB with respect to the direct object complement clauses and purpose clauses discussed in the present article, and the extent to which wNA retains features from earlier Aramaic or has adopted Arabic morphosyntax. ${ }^{141}$

In a different article, the influence of SARB on the function of the wNA verb forms has been examined. ${ }^{142}$ Specifically, it considers the possibility of

141 For contact between WNA and SARB in the areas of phonology, morphology, and lexicon, see Arnold and Behnstedt, Sprachbeziehungen.

142 I.J. Bunis, 'The Morphosyntactic Conservatism of Western Neo-Aramaic Despite Contact with Syrian Arabic', in G. Khan and P. Noorlander (eds.), Studies in the Grammar and Lexicon of Neo-Aramaic (Cambridge Semitic Languages and Cultures 5, Cambridge: University of Cambridge \& Open Book Publishers, 2021) pp. 235-285. 
TABLE 1 Formal similarities of verbal inflection, *pth 'open', G-stem, 3F S

\section{WNA SARB}

\begin{tabular}{|c|c|}
\hline Suffix conjugation & fath-at \\
\hline Prefix conjugation & či-ftuh \\
\hline Historical active participle & fōtha \\
\hline
\end{tabular}

the influence of SARB verb forms on cognate WNA verb forms. Unlike the present article, the perspective there is mostly comparative, not historical. As two related Semitic languages, both SARB and WNA have inherited suffix and prefix conjugations, and a form that historically was an active participle. ${ }^{143} \mathrm{In}$ both languages, these forms are similar-sounding and inflect in a similar fashion. Table 1 illustrates this with respect to the Semitic root "pth 'open', which occurs in both languages in the G-stem.

The cognate WNA and SARB forms differ in their functions. The article claims that although it is common to find differing functions of cognate verb forms in related languages, in the specific case of WNA, the retention of such differing functions reflects conservatism. In support of this claim, the following factors are adduced: (i) the sound-similarity between the cognate forms, (ii) many inherited functions of the suffix and prefix conjugations overlap in both languages, (iii) for centuries WNA speakers have been bilingual, also speaking SARB, (iv) various indications that WNA speakers have been aware of the soundsimilarity and overlapping functions of the WNA and SARB verbal forms. All of these factors created a potential for replicating the functions of the SARB verb forms by the cognate, similar-sounding WNA forms, yet the wNA forms continue functioning independently.

In that article, WNA is not compared with the SARB of bilingual speakers, but rather, with SARB dialects of neighbouring non-WNA speakers. In what follows, I take the further step of comparing the WNA and SARB of an individual bilingual speaker from the village of Ğubb'adinn. Correll published versions of stories narrated by this speaker in the Arabic dialect of Ğubb'adīn, ${ }^{144}$ and in WNA. ${ }^{145}$

143 Grotzfeld, Grammatik, pp. 26-42; Arnold and Behnstedt, Sprachbeziehungen, pp. 12-14, $44-45,51,55-59$.

144 C. Correll, 'Textproben im arabischen Dialekt von Ğubb 'Adīn', ZDMG 122 (1972), pp. 49-87.

145 Correll, Untersuchungen, pp. 150-179. 
The comparison of these texts provides a direct glimpse of this speaker's bilingualism. I adduce a single example (Ex 11ob) from the dialect of Hafï Tahta, a non-WNA speaking village located 31 kilometres southwest of Ma'lūla, because in Correll's SARB texts I found no example of direct object complements of verbs of ability, a type of construction discussed throughout the present article. To complete the picture, I end with general data about the distribution of morphosyntactic constructions in WNA and SARB.

Example 105 illustrates the parallel use of the active participle and Exs 106107 show parallel uses of yiqtol by the bilingual speaker from Ğubb'adīn. All three examples are from the same story in SARB (a) and WNA (b), showing the use of the cognate verb forms, within the same context and syntactic structure.

(105) Cognate active participle

a. SARB, Ğubb'adīin ${ }^{146}$

š-šörța rāyhla dawriyye

DEF-police.Fs go.PART-FS patrol

'The police was on patrol'.

b. WNA, Ğubb'adīin ${ }^{147}$

tawrōyta $\emptyset$-ōz-a 'a- $a$ Guppa ${ }^{`} \underline{O} \underline{d}$

patrol.Fs 3-go.PART-Fs to-Ğubb'⿳adīn

'The/a patrol was going to Ğubb'adīn'.

(106) Cognate yiqtol form: hortative construction

a. SARB, Ğubb'adīn ${ }^{148}$

xall-ī yo-hki-lak hū

let.IMP.2MS-DO.3Ms 3MS-tell.IRR-IO.2Ms he

'Let him tell you'.

b. WNA, Ğubb'adīn ${ }^{149}$

aff-Ø-n̄ $\quad y a-h c c \bar{e}-x$

let.IMP-2MS-DO.3MS 3MS-tell.IRR-IO.2MS

'Let him tell you'.

146 Correll, 'Textproben', p. 54:17.

147 Correll, Untersuchungen, p. 156:7.

148 Correll, 'Textproben', p. 58:54.

149 Correll, Untersuchungen, p. 16o:24. 
(107) Cognate yiqtol form: volition

a. SARB, Ğubb'adīn ${ }^{150}$

badd-i Ø-rudd-u

desire-1s 1s-return.IRR-DO.3MS

'I wish to return it'.

b. WNA, Ğubb'`adīn ${ }^{151}$

bi-n n-'awwt-enni

desire-1S 1-return.IRR-DO.3MS

'I wish to return it'.

SARB possesses a set of preverbal particles that can be added to the bare yiqtol form, including $b$-, rāh $h$ - and ' $a m m \bar{a} l-{ }^{152}$ As in other SAR B dialects, the prefix $b$ is used in the bilingual speaker's Arabic to express the non-past indicative (Ex 108a). In WNA, the same function is performed by the historical active participle, as exemplified by the parallel wNA sentence (Ex 108b).

(108) Non-past indicative: SARB $b$-yiqtol = wNA active participle a. SARB, Ğubb'adīn ${ }^{153}$

$\stackrel{d}{d} b \bar{e}^{c} \quad b$-Ø-ə'rif $\quad$ wèn $\quad b-y-\bar{u} q a^{c}-u$

hyena.PL IND-1S-know.IMPERF where IND-3M-exist.IMPERF-PL 'Hyenas_I know where they are'.

b. WNA, Ğubb'adīn154

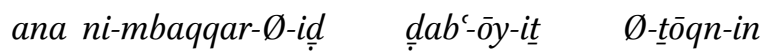

I 1-know.PART-MS-DEF hyena-PL-REL 3-exist.PART-MPL 'I know the hyenas that exist'.

The preverbal particle 'ammāl- and its bi-forms are used in both languages to indicate a progressive or habitual aspect. ${ }^{155}$ In SARB, it commonly occurs in phonologically reduced forms such as 'amma- (Ex 109a), 'am, mma-, ma-. As the parallel examples indicate, unlike in SARB, where it is prefixed to the yiqtol form, in wNA it is prefixed to the active participle (Ex 109b). In both spe-

\footnotetext{
$15^{\circ}$ Correll, 'Textproben', p. 56:40.

$15^{1}$ Correll, Untersuchungen, p. 158:20.

$15^{2}$ Grotzfeld, Grammatik, p. 87.

153 Correll, 'Textproben', p. 55:30.

154 Correll, Untersuchungen, p. 158:16.

155 For WNA, see Correll, Untersuchungen, pp. 61-61.
} 
cific examples, the preverbal element occurs with the same verbal lexeme $s f r$ 'whistle'. Thus, in function, the wNA active participle could be said to parallel both SARB b-yiqtol (Ex 108) and SARB yiqtol (Ex 109).

(109) SAR B 'ammal + yiqtol = WNA 'ammal + active participle (Ǧubb'adīn)

a. SARB, Ğubb'⿳亠口冋in ${ }^{156}$

riža-Ø la-žuwwa 'amma yö-sfur

return.PERF-3MS to-inside PROG 3MS-whistle.IMPERF

'It [the hyena] went back inside whistling'.

b. WNA, Ğubb`adīn ${ }^{157}$
$\underline{t} \bar{e}-\emptyset-l i$
el-ay 'am-Ø-șōfar-Ø
ex
come.PERF-3MS-to-3MS upon-1S PROG-3-whistle.PART-MS like
babūr
kerosene.stove
'It [the hyena] came upon me whistling like a kerosene stove'.

Some of the overlapping functions of the cognate yiqtol conjugations of WNA and SARB are found in its use as an irrealis mood (Exs 106-107, 110). ${ }^{158}$ In SARB, both around the WNA villages and in the dialect of the bilingual speaker, bare yiqtol appears in all irrealis functions performed by wNA yiqtol, surveyed in $\S 5$ above. ${ }^{159}$ Specifically, SARB bare yiqtol occurs in direct object complements of volitional verbs, verbs of ability, and purpose clauses (Exs 110a, b, c, respectively). Also, as in WNA, asyndesis in these contexts is very much widespread, and finite complement clauses may be subject co-referential (Exs 11ob, c) or non-co-referential (Ex 110a) with their matrix clause.

(110) SARB

a. Ğubb`adīn 160

'addēš bi-t-ḩubb yo-xsar-lak

how.much IND-2MS-desire.IMPERF 3MS-pay.IRR-IO.2MS

'How much would you like him to pay you?'

\footnotetext{
156 Correll, 'Textproben', p. 53:9.

157 Correll, Untersuchungen, p. 158:12.

158 See Brustad, Syntax, p. 233.

159 For other SARB dialects neighbouring the WNA-speaking villages, see Bunis, 'Conservatism'.

16o Correll, 'Textproben', p. 58:56.
} 
b. Ḥafïr Taḥta ${ }^{161}$

ma b-yi-'dir $\quad y$-'abbi $\min f \bar{o}^{\prime}$

not IND-3MS-able.IMPERF 3MS-fill.IRR from above

'He is not able to fill from above'.

c. Ğubb'adīn ${ }^{162}$

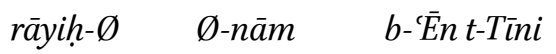

go.PART-MS 1S-sleep.IRR in-'Ēn.et.Tīne

'[I] am going to sleep in 'Ēn et-Tīne'.

In SARB, however, bare yiqtol is used in direct object complements of additional types of CTPS. Inchoative verbs in SARB almost exclusively take finite complements containing bare yiqtol (Ex 111a), and, more rarely, yiqtol prefixed with a preverbal particle (Exs 112a, 113a). In WNA, by contrast, aspectual verbs contrast with verbs of volition and ability, and take complements with an active participle (Ex 111 b and $\S 5.3$ above), which in other contexts parallels SARB b-yiqtol, not the bare yiqtol.

The SARB texts narrated by the bilingual from Ğubb'adīn contain seven occurrences of șār and one of ballaš in inchoative function, complemented by an embedded clause. Five occurrences of $s \bar{a} r$ are complemented by a bare yiqtol form (Ex 111a), and two by 'amma (l)-yiqtol (Ex 112a). The single occurrence of ballaš embeds b-yiqtol (Ex 113a).

By contrast, in the parallel WNA inchoative constructions, there is no use of embedded yiqtol or 'amma $(l)$-active participle, which in other functions respectively parallel the SARB bare yiqtol (Exs 106-107, 110) and 'amma(l)-yiqtol (Ex 109). In Correll's wNA stories from Ğubb'adīn, ten such occurrences are found, a number of which find corresponding sentences in the SARB versions. In all of these, the inchoative verb abtay, itself a loan from the Arabic * $b d^{\text {' }}$ 'begin', takes an active participial complement (Exs 111b, 112b, 113b). Thus, only the occurrence in Exs 113a, b reflects the equivalence between SARB b-yiqtol and the active participle in WNA, which is found in contexts expressing nonpast indicative (Ex 108).

(111) a. SARB, Ğubb`adīn ${ }^{163}$

$w$-șir-na n-ța'mi-hun
and-begin.PER F-1P 1P-feed.IRR-DO.3MPL
'And we began to feed them.

161 Behnstedt, Sprachatlas, p. 380:45.

162 Correll, 'Textproben', p. 65:6.

163 Correll, 'Textproben', p. 62:22. 
b. WNA, Ğubb'adīn ${ }^{164}$

abti-t $\quad n$-mațem- $\emptyset$-li

begin.PERF-1S 1-feed.PART-M S-D O.3M S

'I began to feed it'.

(112) a. SARB, Ğubb'adīn ${ }^{165}$

șār-et 'amma ti-bki

begin.PERF-3FS PROG 3FS-cry.IMPERF

'She [my wife] began to cry'.

b. WNA, Ğubb`adīn ${ }^{166}$

abta-t $\quad \emptyset-b \bar{x} x y-a \quad h \bar{\imath} \quad y \bar{o} l-a y$

begin.PERF-3FS 3-cry.PART-FS she wife.CS-1S

'She began to cry, my wife'.

(113) a. SARB, Ğubb`adīn ${ }^{167}$

w-ballaš- $\varnothing \quad$ l-amal b-yi-țlac

and-begin.PERF-3MS DEF-pus.MS IND-3MS-come.out.IMPERF

min-na

from-3Fs

'And the pus began to come out of it'.

b. WNA, Ğubb`adīn ${ }^{168}$

abtay- $\varnothing \quad \emptyset$-nōfeq- $\emptyset \quad$ men-na amla

begin.PERF-3MS 3-come.out.PART-MS from-3FS pus.MS

'And the pus began to come out of it'.

What is striking here is that the functional parallels surveyed above-namely WNA yiqtol $=$ SARB yiqtol in irrealis contexts, and WNA active participle $=$ SARB b-yiqtol in non-past indicative contexts - have not led to analogical levelling in the function of the WNA forms in the context of aspectual CTPS under SARB influence.

164 Correll, Untersuchungen, p. 162:6.

165 Correll, 'Textproben', p. 54:11.

166 Correll, Untersuchungen, p. 156:4.

167 Correll, 'Textproben', p. 71:45-46.

168 Correll, Untersuchungen, p. 172:5. 
These findings are corroborated by other wNA and SARB texts. ${ }^{169}$ I shall now provide data on the distribution of the relevant morphosyntactic patterns in these languages. In the oral literature in wNA from Malūla published by Werner Arnold, ${ }^{170}$ I have found seventy-six occurrences of inchoative verbs that take complements with an active participle, as in Correll's stories from Ğubb'adīn. These inchoative CTPs include the Aramaic origin $\underline{t} q n$, occurring sixty-two times, as well as the Arabic origin $i b^{\curvearrowright}$ člaš (< Arabic ibtalaš, ten occurrences), balleš (< Arabic ballaš, one occurrence), and apt (< Arabic $b d^{\prime}$, three occurrences). Only one occurrence was found there of balleš + yiqtol (10:14), which perhaps reflects the Arabic syntagm (Ex 111a). By contrast, in SARB texts from the Qalamun region of wNA published by Peter Behnstedt, ${ }^{171}$ and texts in Damascene Arabic published by Heinz Grotzfeld ${ }^{172}$ and Kristen Brustad, ${ }^{173}$ as well as texts of Christian Lebanese Arabic from Beirut (around 10o kilometres west of Ma'ūla) published by Henry Huxley, ${ }^{174}$ I have found inchoative șār + yiqtol over forty times. The same syntagm is found with ballaš once, and bidi $\left(<^{*} b d^{3}\right)$ twice. Other syntagms are rare; in Brustad's texts șār + 'amma $(l)$-yiqtol is found once, and in the texts in Lebanese Arabic șār + active participle is found once.

To summarise this section, the morphosyntax of wNA direct object complement clauses and purpose clauses partially resembles that of SARB. Firstly, the manner of attachment is similar: (i) in both languages asyndesis is common, and (ii) for syndetic attachment, WNA employs Arabic subordinators $(\S 5.2)$, and in the case of direct object complements also non-Arabic forms. These, however, may be calques of SARB $(\$ 5.2)$. Secondly, the form of the subordinate verb is cognate yiqtol in both languages, in direct object complements of verbs of volition and ability, and in purpose clauses. However, the two languages diverge with respect to aspectual, especially inchoative complement taking verbs. SARB does not distinguish between these verbs and verbs of volition and ability, and all take complements in yiqtol. wNA on the other hand employs the active participle, which in other contexts does not functionally

169 See Bunis, 'Conservatism'; Correll, Untersuchungen, pp. 62-63.

170 Arnold, Orale Literatur.

171 P. Behnstedt, Sprachatlas von Syrien. 2. Volkskundliche Texte (Semitica Viva, 17, Wiesbaden: Harrassowitz, 1997-2000) pp. 308-381.

172 H. Grotzfeld, Syrisch-Arabische Grammatik (Dialekt von Damaskus) (Porta Linguarum Orientalium: Neue Serie, viI, Wiesbaden: Harrassowitz, 1965) pp. 118-149.

173 K.E. Brustad, The Syntax of Spoken Arabic: A Comparative Study of Moroccan, Egyptian, Syrian, and Kuwaiti Dialects (Washington, D.C.: Georgetown University Press, 2000) pp. 395408.

174 H.M. Huxley, 'Syrian Songs, Proverbs, and Stories; Collected, Translated, and Annotated', JAOS 23 (1902), pp. 175-288. 
parallel SAR в bare yiqtol, but rather b-yiqtol. In the concluding discussion that follows I relate these findings to earlier Aramaic.

\section{$7 \quad$ Conclusions}

The present article seeks to illuminate the historical development of the morphosyntax of direct object complement clauses and purpose clauses in Western Neo-Aramaic. For this purpose, it provides a historical study of the morphosyntax of direct object clauses and purpose clauses in Aramaic, especially its western branch. The analysis goes in chronological order, focusing first on Old, Official, Biblical, and Qumran Aramaic ( $(2)$. The discussion then moves on to Late Aramaic, first looking at Syriac (§3), and then the three Western Late Aramaic dialects (CPA, JPA, SA, §4). Lastly, the study looks at direct object and purpose clauses in Western Neo-Aramaic $\left(\S_{5}\right)$ in contact with Syrian Arabic (§6). The analysis reveals a series of morphosyntactic changes with respect to Aramaic direct object clauses and purpose clauses that would appear to correlate mostly with chronology and region.

At the earlier stages of Aramaic, the clauses analysed may take the form of infinitive clauses governed by the matrix verb through the originally prepositional element $l$. The infinitive was already found to form both direct object and purpose clauses in Old Aramaic (the Sefire inscriptions), ${ }^{175}$ and then in Official Egyptian Aramaic, Biblical Aramaic, Qumran Aramaic (\$2.1). There appears not to have been any restriction on the class of matrix verb governing the infinitive in the varieties in which it is found, as reflected by its use in complementing verbs of volition and ability, and aspectual verbs. The use of infinitive clauses is restricted in that their subject must co-refer with that of the matrix clause, except with the specific class of manipulative matrix verbs. In pre-LA, the embedded infinitive, in both syntactic functions, regularly exhibits the prefix $l$-, as a subordinator. The infinitive continues to form direct object and purpose clauses in Late Aramaic in both the Western branch (JPA, SA, § 4.1) and outside of it (Syriac, § 3.1). In Syriac the use of $l$ - with the infinitive is so widespread as to justify considering it part of the morphology of the infinitive. In WLA we find a morphosyntactic innovation: although the infinitive sometimes appears with the subordinator $l$-, it now appears more commonly without it, in both direct object and purpose clauses. One variety of WLA, CPA, attests to the decline and abandonment of the infinitive to form embedded

175 See Pat-El, Syntax, 21, pp. 34-35. 
clauses, and its replacement with finite and participial verb forms. An analogous development has taken place in wNA in all three of its dialects $(\S 5.1)$. In Syrian Arabic too, infinitives or verbal nouns are rarely used.

Already as early as $\mathrm{OA}$, finite clauses appear as an alternative to infinitive clauses in direct object clauses and, from OFEA onward, in purpose clauses as well ( $§ 2.2)$. As direct objects, they complement verbs of ability in all the varieties examined except for BA, and also JPA at the LA stage ( $\$ 4.2$ ). In OFEA this use is much more common (fifty occurrences) than infinitival clauses (twice). Volitional verbs complemented by finite clauses are attested as early as OFEA (three occurrences), and they are also used in all later dialects examined.

The corpora of the Aramaic varieties examined differ with respect to subject co-reference of the main and finite subordinate clauses. In OA and OFEA, both possibilities occur, with the majority of finite direct objects being subject co-referential ( $\$ 2.2 .2)$. Later on, LA and then wNA show the same use of both possibilities $(\S \S 3.2,4.2,5 \cdot 2)$. This feature also characterises SARB $(\S 6)$.

$\mathrm{BA}$ and QA-chronologically intermediate between OFEA and LA—stand out as exceptional, since all finite complements are subject non-co-referential and appear in complementary distribution with infinitival direct objects that are subject co-referential ( $§$ 2.2.1), except for a single occurrence in QA ( $\$$ 2.2.2, Ex 19). This single occurrence of a finite, subject co-referential complement of $y k l$ 'able' suggests that the construction persisted in speech from the earlier stages of Aramaic but was avoided in the standard language of BA and QA, for reasons such as style or register.

One sub-type of finite direct object complement strategy shows 'tense copying' of the Стр by the complement verb, which may be considered verb serialisation $(\S 1)$. This is attested in pre-LA, in OA and OFEA $(\S 2.2 .2)$, in yiqtol (verbs of ability) and qtal (once with verb of ability [Ex 13], and perhaps once with šry 'begin', [Ex 14]). In LA it is very typical of Syriac with finite, participial, and adjectival CTPS (of ability and aspect, $\S 3.2 .2, \S 3 \cdot 3$ ). In WLA this type of construction is only found with participial and adjectival CTP s of ability and aspect (§4.3). Perhaps this is a retention from a situation more like Syriac in which serialisation also occurred with finite CTPs. This complementation strategy is unattested in WNA and SARB. This is summarised in table 2.

A complex structural and chronological picture is revealed with respect to the formal linking of finite clauses. With regard to direct object clauses, in OA and OFEA, all but one of the fifty-three recorded finite clauses examined are asyndetic ( $\$$ 2.2.2). By contrast, in BA and QA, all finite complement clauses are embedded by $d y$-, though otherwise they have the same structure ( $\$ 2.2 .1)$. The single co-referential exception in QA is also asyndetic, as in OA and OFEA (Ex 19). Later on, in Syriac (§§ 3.2.1-3.2.2), CPA, and JPA (§§ 4.2.1-4.2.2) the two 
TABLE 2 Serial verb constructions from OA to WNA

\begin{tabular}{|c|c|c|c|c|}
\hline & \multicolumn{3}{|l|}{ Form/class of CTP } & \multirow{2}{*}{$\begin{array}{l}\text { Negation } \\
(\text { See } \S 2.2 .2)\end{array}$} \\
\hline & qtal & yiqtol & $\begin{array}{l}\text { Active } \\
\text { participle/ } \\
\text { adjective }\end{array}$ & \\
\hline OA & & $\bullet$ & & Concordant \\
\hline OFEA & $\begin{array}{l}\bullet(\times 2 \text { ?, ability, } \\
\text { 'begin') }\end{array}$ & $\bullet$ & & Single \\
\hline \multicolumn{5}{|l|}{ BA } \\
\hline $\mathrm{QA}$ & & - $(\times 1$ ? , ability $)$ & & \\
\hline Syriac & - (ability, aspect) & - (ability, aspect) & - (ability, aspect) & Single \\
\hline WLA & & & - (ability, aspect) & Single \\
\hline \multicolumn{5}{|l|}{ WNA } \\
\hline SARB & & & & \\
\hline
\end{tabular}

options (with and without $d$ - as the subordinator) constitute alternatives. In SA, asyndesis is nearly exclusive, with only vestiges of the use of $d-(\S 4.2 .1)$. In the chronologically latest WNA, asyndesis is widespread — but syndetic clauses are also found, linked not by a reflex of $d$-, but by forms borrowed from Arabic, or by the innovative forms $\underline{d} \bar{o} b$, lōb $(\S 5.2)$. Both syndetic linking and asyndesis is found in SARB.

A similar picture is reflected with finite purpose clauses. Some three subject non-co-referential, asyndetic occurrences are found in OFEA (\$ 2.2.2). In BA and QA, they only appear when subject non-co-referential with the main clause and they are syndetically subordinated by $d y$ - ( $\$$ 2.2.1). Later on, in LA and WNA $(\S \S 3.2,4.2,5.2)$, there is no restraint concerning subject co-reference. Both syndesis and asyndesis occur, except for SA, where finite purpose clauses are always asyndetic. In wNA syndetic clauses linked by Arabic-origin subordinators are more common, but asyndesis is frequent with matrix verbs of motion, analogously to the earlier varieties of Aramaic.

Throughout the varieties examined, a correlation is found between direct object complement clause morphosyntax, and the aspectual and modal context. The complement verb is consistently in yiqtol in volitional contexts, which include direct object complements of volitional СтРs and purpose clauses $(\S \S 2.2,3.2,4.2,5.2)$. This is apparently due to the intrinsic irrealis modality of these clauses, which is closely related to non-past tense or imperfect aspect. 
TABLE 3 Verb form and linkage of direct object complement clauses and purpose clauses from OA to WNA

\begin{tabular}{|c|c|c|c|c|c|c|}
\hline & $\begin{array}{l}\text { Infinitive } \\
l- \\
\text { infinitive }\end{array}$ & $\begin{array}{l}\text { Bare } \\
\text { infinitive }\end{array}$ & $\begin{array}{l}\text { yiqtol } \\
\text { d- } \\
\text { yiqtol }\end{array}$ & $\begin{array}{l}\text { Asyndetic } \\
\text { yiqtol }\end{array}$ & $\begin{array}{l}\text { Tense copying / } \\
\text { verb serialisation }\end{array}$ & $\begin{array}{l}\text { Active } \\
\text { participle }\end{array}$ \\
\hline Pre-LA & $\bullet$ & & & $\bullet$ & $\bullet$ & \\
\hline Syriac & $\bullet$ & & $\bullet$ & $\bullet$ & $\bullet$ & $\bullet$ \\
\hline JPA & $\bullet$ & $\bullet$ & $\bullet$ & $\bullet$ & Limited to & $\bullet$ \\
\hline SA & $\bullet$ & $\bullet$ & & $\bullet$ & participle/adjective & $\bullet$ \\
\hline СРA & & & $\bullet$ & $\bullet$ & + participle & $\bullet$ \\
\hline WNA & & & & $\bullet$ & & $\bullet$ \\
\hline SARB & & & & $\bullet$ & & \\
\hline
\end{tabular}

In WLA yiqtol appears to have been fully specialised as a subjunctive which is only used for irrealis $(\$ 5 \cdot 2)$. CT P s of ability and aspect reflect intra- and interdialectal fluctuation between taking complements in yiqtol, as in volitional contexts, serialised complements copying the tense/aspect of the CTP, and taking a participial complement, regardless of the form of the CTP. In JPA alone, verbs of ability do not take complements in yiqtol ( $\$ \$ 4.2-4 \cdot 3)$. In WNA, yiqtol is embedded in volitional contexts and by verbs of ability, but not by aspectual verbs $(\S \S 5 \cdot 2-5 \cdot 3)$. By contrast, SARB employs its cognate yiqtol form for all direct object complements $(\S 6)$.

Table 3 summarises these developments in the Aramaic dialects examined in the present article.

An apparent innovation of LA is the use of the active participle as the embedded verb in direct object complements $(\S \S 3 \cdot 3,4 \cdot 3)$, which correlates with the aforementioned specialisation of yiqtol as an irrealis mood. The participle by contrast complements aspectual predicates. Verbs of ability occupy a middle ground and vary among the dialects of LA in whether they also embed yiqtol forms. In JPA only participles and infinitives are permitted $(\$ 4.1-3)$. In the other LA dialects, an embedded yiqtol form is allowed as well $(\S \S 3.2,4.2)$. In WLA, and somewhat less so in Syriac, the inchoative verb šry (D-stem) shows an almost absolute preference for embedding an active participle $(\S \S 3 \cdot 3,4 \cdot 3)$. Again departing from the morphosyntax of contact Arabic, wNA also shows an almost absolute preference for an embedded participle in complement- 
ing inchoative matrix verbs, even with matrix verbal lexemes borrowed from SARB - although SARB does not use this construction ( $§ 5.3, \S 6)$.

To assess the degree to which wNA has retained the morphosyntax of LA in its use of embedded clauses or has developed away from LA under the apparent influence of SARB, WNA, and SARB were compared (§6). In some features the two closely resemble each other. As in WNA, finite embedded clauses, rather than infinitives, are used overwhelmingly in SARB. In WNA and SARB, such clauses can be subject co-referential or non-co-referential with the matrix clause. Moreover, they can function both as direct object complements and purpose clauses. Also, as in WNA, asyndetic finite embedded clauses are common in SARB. But as was shown, all of these features are already found in earlier Aramaic as well, and thus it is hard to determine whether the congruity is due to the influence of SARB morphosyntax, or to preservation of earlier Aramaic morphosyntax.

Nonetheless, the comparison between WNA and SARB indicates that WNA has retained at least one grammatical distinction found in LA but not in SARB, namely, in wNA embedded yiqtol is used for irrealis whereas the active participle complements aspectual predicates $(\S \S 5 \cdot 2,5 \cdot 3)$. SARB shares with wNA the existence of cognate yiqtol and active participle forms, and the forms in the two groups even overlap in some functions. Nonetheless, in SARB, as distinct from WNA, embedded yiqtol is used not only in volitional contexts and with matrix verbs of ability, but also in complements of inchoative verbs $(\S 6)$.

WNA is the sole surviving heir to the Western Aramaic varieties that were used in Syro-Palestine. The present article has shown that, on the whole, wNA reflects a combination of features and developments observed in various earlier Aramaic dialects from OA to LA. As in CPA, the infinitive is no longer used in WNA to form embedded clauses. In WNA, asyndetic finite direct object clauses and bare purpose clauses, which are found in OA, OFEA and LA, are common. Reflexes of the Aramaic subordinator $d$ - are not used in WNA in the syndetic counterparts of these embedded clauses, but rather innovative native forms or Arabic-origin subordinators. This contrasts with relative clauses and genitive constructions in WNA in which $t i$-, a reflex of $d$-, is retained as a relativiser $(\S 5.2)$. This distribution of $t i$ - parallels the distribution of $d$ - in SA $(\S \S 4.2 .1,5.2)$. This may indicate that, as in $\mathrm{SA}$, when the precursors of wNA came into contact with Arabic, syndetic linking though Aramaic $d$-had already been lost with finite direct object clauses and bare purpose clauses, but not relative clauses. Later on, syndesis was re-established through subordinators that were borrowed from Arabic or innovated on the basis of Arabic. The yiqtol conjugation and active participle in WNA retain the respective functions they had in LA. Some constructions that had existed in earlier Aramaic, such as serialisa- 
TABLE 4 Use of verb forms in direct object complement clauses and purpose clauses according to the modal and aspectual context

\begin{tabular}{llll}
\hline & $\begin{array}{l}\text { Volitional CTP and } \\
\text { purpose clause }\end{array}$ & Ability CTP & Aspectual CTP \\
& & & \\
Infinitive & Pre-LA; Syriac; LWA & Pre-LA; Syriac; WLA & $\begin{array}{l}\text { Pre-LA; Syriac } \\
\text { Very rare in WLA }\end{array}$ \\
Asyndetic & OFEA & OA, OFEA, QA (×1) & SARB \\
yiqtol & Syriac; JPA, SA, CPA & $\begin{array}{l}\text { Syriac; SA, CPA } \\
\text { WNA }\end{array}$ & \\
& WNA & SARB & \\
& SARB & Syriac & Syriac, CPA \\
d-yiqtol & BA, QA; Syriac; JPA, CPA & Syriac; JPA, SA, CPA & Syriac; JPA, SA, CPA \\
& & & WNA \\
\hline participle & Uncommon: Syriac, SA, & SyA & \\
& CPA & &
\end{tabular}

tion with verbs of ability, are not attested in wNA. The significant contribution made by contact Arabic to WNA in the areas of lexicon, as well as syntax, has been widely acknowledged; but it would appear that, at least with respect to the clauses examined in the current article, the influence of SARB on WNA at the level of morphosyntax is confined to the use of Arabic subordinators. Otherwise, the influence of SARB is limited to lexical borrowing in the form of Arabic matrix verbal lexemes.

Table 4 summarises the use of verb forms in direct object complement clauses and purpose clauses, according to the modal and aspectual context. 